\title{
Natural mortality of marine pelagic fish eggs and larvae: role of spatial patchiness
}

\author{
Michael D. McGurk* \\ Institute of Animal Resource Ecology, The University of British Columbia, 2204 Main Mall, Vancouver, \\ British Columbia V6T 1W5, Canada
}

\begin{abstract}
Daily instantaneous natural mortality rates of marine pelagic fish eggs and larvae are higher than expected from the trend of mortality rate with dry weight in the sea. The difference between observed mortality rates and those predicted from the trend of mortality with dry weight is directly and positively correlated with the patchiness of their spatial distribution, which suggests that it is caused by the feeding of predators on patches of eggs and larvae. The product of weight-dependent mortality, $5.26 \times 10^{-3} W^{-0.25}$, and $1+$ Lloyd's patchiness index predicts mortality rates close to those that have been measured from the field by other workers. Mechanisms that control the spatial patchiness of eggs and larvae may control early life history survival and thereby influence relative year-class strength of adult fish stocks.
\end{abstract}

\section{INTRODUCTION}

Mathematical models of mortality rate in marine pelagic organisms have been based mainly on sizedepenuteni preciaion (Ursin 1967, Ware 1975, Peterson $\&$ Wroblewski 1984). The inherent assumption of these models is that predation occurs everywhere at the same rate, but this is not a realistic assumption because predation in a real aquatic ecosystem depends on the spatial distribution of both predators and prey. The act of predation includes search time as well as feeding time, which implies that the spatial distribution of prey influences both the fraction of the total time spent by a predator searching for prey, and the intensity of feeding (number of attacks per unit time spent feeding) once a predator has located prey.

The maximum effect of spatial distribution on mortality rate occurs in the limiting case where the time required by a predator to handle (capture and consume) a prey item is very much smaller than the total time. In this case a predator's feeding rate is not limited by handling time and it can attack every prey item it encounters. In such a situation the mortality rate inflicted on a prey population by a predator population is mainly controlled by 2 correlated variables: the time available for feeding, and the density of the prey

- Present address: Envirocon Pacific Ltd., 205-2250 Boundary Road, Burnaby, British Columbia V5M 3Z3, Canada patches. The variables are correlated because they are different aspects of a single phenomenon: spatial patchiness. The fraction of the total time that is spent searching for prey is directly proportional to the fraction of the total area that is empty of prey, and the density of prey in the remaining area is directly proportional to the fraction of the total area that is empty of prey.

The situation of negligible handling time occurs in nature for at least one group of prey: pelagic fish eggs and larvae. Fish eggs and newly-hatched larvae have poorly developed sensory systems, skeleton, and musculature. The eggs cannot evade capture once a predator has fixed its attention on them, and newly-hatched larvae have only a marginally improved evasion capability. However, once fish larvae begin to school, if they are a pelagic species, or migrate to the ocean floor, if they are a demersal species, the situation of negligible handling time may no longer apply. At this age and size a fish develops predator avoidance behaviour and the handling time of its predator increases towards the level where the natural mortality rate of the fish and its spatial distribution become uncoupled.

Fish eggs and larvae are known to be patchily distributed in space (Smith 1973, Hewitt 1981, Houde \& Lóvdal 1985, Koslow et al. 1985, McGurk 1986). This implies that natural mortality rates of fish eggs and larvae are higher than would be expected from the 
general trend of mortality with weight in the sea, because predators have a higher feeding rate on patches of prey than on a uniform or randomly distributed prey. Peterson \& Wroblewski (1984) noted that mortality rates of some species of fish larvae with a mean dry weight between $1 \times 10^{-4}$ and $1 \times 10^{-2} \mathrm{~g}$ were higher than expected from the overall trend of mortality rate with dry weight for fish.

This paper describes a model of mortality rate in marine pelagic fish eggs and larvae that combines the weight-dependence of previous models with an index of the spatial patchiness of the eggs and larvae. First, the model and its assumptions are described. Second, a large body of published data is used to demonstrate that mortality rates of marine pelagic fish eggs and larvae are 5 to 10 times higher than rates expected from their dry weight. Third, it is shown that this difference in mortality rates can be explained as the result of the reaction of predators to the spatial patchiness of the eggs and larvae. Finally, the implications of this patchiness-mortality interaction for the study of the population dynamics of fish eggs and larvae, and for the general theory of fishing, are discussed.

\section{MODEL OF MORTALITY-PATCHINESS INTERACTION}

The exponential rate of natural mortality for fish eggs and larvae is assumed to be the product of the expression for the weight-dependence of mortality, $M_{w}\left(\mathrm{~d}^{-1}\right)$, and a function of patchiness, $H(p)$,

$$
\frac{1}{N} \frac{d N}{d t}=-M_{w} \cdot H(p)
$$

where $N=$ the number of eggs and larvae; $t=$ time (d). $M_{w}$ is assumed to decrease with increasing body weight of the prey in the pelagic ecosystem according to Peterson \& Wroblewski's (1984) model,

$$
M_{w}=5.26 \times 10^{-3} W^{-0.25},
$$

where $W=$ dry body weight $(\mathrm{g})$. This model was based on a combination of biomass spectrum theory and bioenergetics principles. It is not a regression model. It was found to describe well the trend of decreasing mortality rate with increasing size for juvenile and adult fishes.

A simple and appropriate index of spatial patchiness is Lloyd's index (Lloyd 1967, Pielou 1977),

$$
p=1+\left(\sigma^{2} \bar{x}^{-1}-1\right) \bar{x}^{-1}
$$

where $\bar{x}=$ the mean density of eggs or larvae for a cruise; $\sigma^{2}=$ the variance of $x$. This index measures the actual crowding of an individual, relative to the average crowding expected in a randomly dispersed population. In a randomly distributed population each individual occupies its own individual space. If the distribution becomes more non-random each individual comes to share its space with 'crowders'. Lloyd's index is equal to the number of 'crowders' per personal space. It is probably the best index of spatial patchiness because it has some biological meaning, it is independent of density, and it is theoretically independent of the scale of sampling. Pielou (1977) presented a mathematical argument based on the Poisson distribution that demonstrated the latter point. However, the empirical relation between Lloyd's index and sampling scale for ichthyoplankton is unknown.

Predators of fish eggs and larvae move through spaces that are empty of prey as well as spaces that contain prey. Therefore, any hypothesis that links predation mortality with spatial patchiness must be tested with data that contains both zero counts and non-zero counts. An examination of the effect of including zero counts on patchiness reveals a simple empirical law: patchiness calculated from data including zero counts, $p_{1}$, is always higher than patchiness calculated from data excluding zero counts, $p$, and the fractional change in patchiness is exactly equal to the fraction of zero counts among the total samples, $\frac{n_{1}}{n}$, i.e.

$$
1-\frac{p}{p_{1}}=\frac{n_{1}}{n}
$$

Rearranging Eqn (4) for $p_{1}$ gives

$$
p_{1}=p\left(1-\frac{n_{1}}{n}\right)^{-1}
$$

The ratio $\frac{n_{1}}{n}$ in Eqn (5) is equal to that fraction of the total time that is spent searching for food in empty space. Therefore, $1-\frac{n_{1}}{n}$ is equal to the fraction of the total time that is spent feeding in a patch, and $p_{1}$ is the ratio of the relative number of prey 'crowders' ingested to the fraction of total time that is spent feeding in a patch. $p_{1}$ is, in fact, the ratio of the 2 correlated variables discussed above that are thought to control the rate of predation in the case where handling time is negligible. It is an index of the intensity of predation; as the ratio $\frac{n_{1}}{n}$ increases, a predator spends more time searching empty space, but when it encounters a patch it feeds more rapidly and efficiently than it would if the prey were distributed more randomly in space.

The hypothesis proposed in this paper is that $H(p)$ varies directly with $1+p_{1}$, one for the occupant of a personal space plus the number of 'crowders' that share its space. Therefore, the complete model is

$$
\frac{1}{N} \frac{d N}{d t}=-5.26 \times 10^{-3} W^{-0.25}\left(1+p_{1}\right)
$$




\section{SOURCES OF DATA}

Lists of data sources used in this paper are given in Table 1 and the Appendix. Table 1 lists mortality rates for populations of fish eggs and larvae with accompanying patchiness values. All other mortality rates are included in the Appendix. The total mortality rates of fish eggs, larvae, and juveniles, and of pelagic invertebrates were estimated as the slopes of the righthand limbs of the catch curves $\log _{e}$ density on age: Ricker 1975). The catch curves of larval fishes spanned the first-feeding stage. The natural mortality rates of adult fishes and whales were calculated from several methods: catch curves of virgin populations; Beverton

Table 1. Natural mortality rates, $M$, dry weights, W, and spatial patchiness of marine pelagic fish eggs and larvae. Mortality rates for fish eggs and larvae that are not accompanied by estimates of patchiness are listed in the Appendix. V: average volume of water filtered in one plankton-net tow; A: total area surveyed during one cruise; N: number of sampling stations occupied during the cruise; a: area per sampling station. The mean patchiness is the geometric mean weighted by the number of samples taken on each cruise; n: number of cruises or number of ages for which patchiness was reported. Dashes: missing data

\begin{tabular}{|c|c|c|c|c|c|c|c|c|c|c|c|}
\hline \multirow[t]{2}{*}{ Species } & \multirow[t]{2}{*}{ Area } & \multirow{2}{*}{$\frac{M}{\left(d^{-1}\right)}$} & \multirow{2}{*}{$\begin{array}{l}W \\
(g)\end{array}$} & \multirow{2}{*}{$\begin{array}{c}V \\
\left(m^{3}\right)\end{array}$} & \multirow{2}{*}{$\begin{array}{c}\mathrm{A} \\
\left(\mathrm{km}^{2}\right)\end{array}$} & \multirow[t]{2}{*}{$\mathrm{N}$} & \multirow{2}{*}{$\begin{array}{c}a \\
\left(\mathrm{~km}^{2}\right)\end{array}$} & \multicolumn{3}{|c|}{ Patchiness } & \multirow[t]{2}{*}{ Source } \\
\hline & & & & & & & & $\overline{\mathrm{x}}$ & $\mathrm{SD}$ & $\mathrm{n}$ & \\
\hline \multicolumn{12}{|l|}{ Fish eggs } \\
\hline \multirow{2}{*}{$\begin{array}{l}\text { Chrysophrys } \\
\text { auratus }\end{array}$} & Hauraki Gulf, & 1.01 & $8.4 \times 10^{-5}$ & $50-300$ & $4.5 \times 10^{3}$ & 42 & $1.07 \times 10^{2}$ & 6.75 & 1.84 & 7 & \multirow[t]{2}{*}{ Crossland (1980) } \\
\hline & New Zealand & 0.30 & $8.4 \times 10^{-5}$ & $50-300$ & $4.5 \times 10^{3}$ & 47 & $8.06 \times 10$ & 5.00 & 1.46 & 9 & \\
\hline $\begin{array}{l}\text { Melanogrammus } \\
\text { aeglefinus }\end{array}$ & $\begin{array}{c}\text { Browns Bank } \\
\text { Nova Scotia }\end{array}$ & $0.38^{\mathrm{d}}$ & $3.2 \times 10^{-4}$ & - & $9.4 \times 10^{3}$ & 27 & $3.48 \times 10^{2}$ & $3.32^{b}$ & 1.31 & 8 & Koslow et al. (1985) \\
\hline \multirow{2}{*}{$\begin{array}{l}\text { Pleuronectes } \\
\text { platessa }\end{array}$} & English Channel & 0.08 & $8.4 \times 10^{-4}$ & - & $1.3 \times 10^{4}$ & - & - & 1.00 & - & - & \multirow{2}{*}{$\begin{array}{l}\text { Harding \& Talbot } \\
\text { (1973), Talbot (1977) }\end{array}$} \\
\hline & & 0.02 & $8.4 \times 10^{-4}$ & - & $1.3 \times 10^{4}$ & - & - & 1.00 & - & - & \\
\hline $\begin{array}{l}\text { Sardinops } \\
\text { sagax }\end{array}$ & S California coast & 0.31 & $5.2 \times 10^{-4}$ & 500 & $6.1 \times 10^{5}$ & 202 & $3.02 \times 10^{3}$ & $22.42^{\mathrm{b}}$ & 1.98 & 16 & $\begin{array}{l}\text { Ahlstrom (1966) } \\
\text { Smith (1973) }\end{array}$ \\
\hline \multirow[t]{2}{*}{$\begin{array}{l}\text { Scomber } \\
\text { scombrus }\end{array}$} & $\begin{array}{l}\text { NE Atlantic coast, } \\
\text { USA }\end{array}$ & 0.13 & $1.4 \times 10^{-4}$ & 850 & $6.8 \times 10^{4}$ & 33 & $2.05 \times 10^{3}$ & 6.32 & 1.31 & 7 & Sette (1943) \\
\hline & $\begin{array}{l}\text { NE Atlantic coast, } \\
\text { USA }\end{array}$ & 0.88 & $1.4 \times 10^{-4}$ & - & $1.3 \times 10^{5}$ & 191 & $6.95 \times 10^{2}$ & 12.74 & 1.28 & 5 & Berrien et al. (1981) \\
\hline \multicolumn{12}{|l|}{ Fish larvae } \\
\hline $\begin{array}{l}\text { Archosargus } \\
\text { rhomboidalis }\end{array}$ & $\begin{array}{l}\text { Terminos Lagoon, } \\
\text { SE Mexico }\end{array}$ & 0.43 & $9.2 \times 10^{-5}$ & - & $1.6 \times 10^{3}$ & 17 & $9.24 \times 10$ & 9.80 & 1.69 & 7 & \multirow[t]{2}{*}{$\begin{array}{l}\text { Stepien (1976). Cha- } \\
\text { vance et al. (1984) }\end{array}$} \\
\hline \multirow{4}{*}{$\begin{array}{l}\text { Clupea harengus } \\
\text { pallasi }\end{array}$} & Barkley Sound. & 0.09 & $1.6 \times 10^{-3}$ & 207 & $4.16 \times 10$ & 9 & 4.51 & 1.86 & 1.48 & 4 & \\
\hline & Vancouver Is. & 0.09 & $1.6 \times 10^{-3}$ & 207 & $4.16 \times 10$ & 9 & 4.51 & 2.13 & 1.57 & 22 & \multirow{3}{*}{ McGurk (1986) } \\
\hline & & 0.06 & $1.6 \times 10^{-3}$ & 207 & $4.16 \times 10$ & 9 & 4.51 & 1.86 & 1.48 & 13 & \\
\hline & & 0.31 & $1.6 \times 10^{-3}$ & 207 & $4.16 \times 10$ & 9 & 4.51 & 1.77 & 1.64 & 13 & \\
\hline $\begin{array}{l}\text { Engraulis } \\
\text { mordax }\end{array}$ & $\begin{array}{l}\text { S California } \\
\text { coast }\end{array}$ & $0.22^{c}$ & $7.0 \times 10^{-4}$ & 500 & $6.1 \times 10^{5}$ & 202 & $3.0 \times 10^{3}$ & $16.79^{b d}$ & 1.34 & 13 & $\begin{array}{l}\text { Ahlstrom (1966), } \\
\text { Zweifel \& Lasker } \\
\text { (1976), Hewitt (1981), } \\
\text { Zweifel \& Smith } \\
\text { (1981), Hewitt \& } \\
\text { Methot (1982) }\end{array}$ \\
\hline $\begin{array}{l}\text { Pleuronectes } \\
\text { platessa }\end{array}$ & English Channel & $0.08^{\circ}$ & $7.5 \times 10^{-4}$ & - & $1.3 \times 10^{4}$ & - & - & 1.00 & - & - & $\begin{array}{l}\text { Harding \& Talbot } \\
\text { (1973), Talbot (1977) }\end{array}$ \\
\hline $\begin{array}{l}\text { Sardinella } \\
\text { aurita }\end{array}$ & $\begin{array}{l}\text { Senegal-Gambia } \\
\text { coast }\end{array}$ & 0.45 & $3.6 \times 10^{-4}$ & - & $7.1 \times 10^{4}$ & 46 & $1.5 \times 10^{3}$ & 11.39 & 1.76 & 11 & $\begin{array}{l}\text { Conand \& Fagetti } \\
(1971), \text { Zweifel \& } \\
\text { Lasker (1976) } \\
\text { Conand (1977) }\end{array}$ \\
\hline $\begin{array}{l}\text { Scomber } \\
\text { scombrus }\end{array}$ & $\begin{array}{l}\text { NE Atlantic coast } \\
\text { USA }\end{array}$ & 0.35 & $3.0 \times 10^{-4}$ & 850 & $6.8 \times 10^{4}$ & 33 & $2.1 \times 10^{3}$ & 5.38 & 1.26 & 9 & $\begin{array}{l}\text { Sette (1943), Kendall \& } \\
\text { Gordon (1981), Ware } \\
\text { \& Lambert (1985) }\end{array}$ \\
\hline \multirow[t]{3}{*}{ Sebastes spp. } & Flemish Cap. & 0.05 & $3.8 \times 10^{-3}$ & - & $5.8 \times 10^{4}$ & 42 & $1.4 \times 10^{3}$ & 3.53 & 1.51 & 3 & \multirow[t]{3}{*}{ Anderson $(1984)$} \\
\hline & NW Atlantic & 0.05 & $3.8 \times 10^{-3}$ & - & $5.8 \times 10^{4}$ & 42 & $1.4 \times 10^{3}$ & 2.43 & 1.09 & 3 & \\
\hline & & 0.07 & $3.8 \times 10^{-3}$ & - & $5.8 \times 10^{4}$ & 42 & $1.4 \times 10^{3}$ & 1.05 & 1.55 & 4 & \\
\hline $\begin{array}{l}\text { Trachunus } \\
\text { symmetricus }\end{array}$ & $\begin{array}{l}\text { S California } \\
\text { coast }\end{array}$ & $0.78^{t}$ & $4.0 \times 10^{-4}$ & 500 & $6.10 \times 10^{5}$ & 202 & $3.02 \times 10^{3}$ & $15.83^{\mathrm{b}, \mathrm{d}}$ & 1.41 & 9 & $\begin{array}{l}\text { Ahlstrom (1966). } \\
\text { Hewitt (1981), } \\
\text { Hewitt et al. (1985) }\end{array}$ \\
\hline \multicolumn{12}{|c|}{ 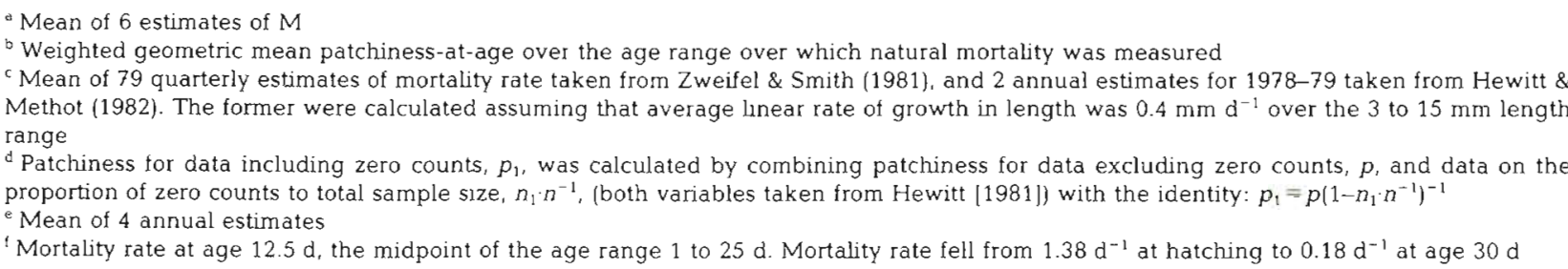 } \\
\hline
\end{tabular}


\& Holt's (1957), Pauli's (1963), and Joseph \& Calkin's (1969) tag-recovery methods; regressions of total mortality on fishing effort to find the intercept when fishing effort was zero; and Beverton \& Holt's (1956) method of calculating mortality rates from the parameters of the growth equation and the average length of the catch. No distinction was made between pelagic or demersal adult fish.

Dry weight was assumed to be $20 \%$ of wet weight. Some universal assumption had to be made because the proximate compositions of many aquatic organisms are not available in the literature. The same assumption was used by Peterson \& Wroblewski (1984) and others.

Wet weight was calculated from the midpoint of the length range that spanned the time period over which the mortality rate was measured using a weight-length equation for that species. An equation for a closely related species was employed if a weight-length equation was not available. This procedure is acceptable as long as the body shapes of the 2 species are similar, e.g. early post-yolk-sac clupeid larvae.

The average length was calculated as the definite integral of the length-age equation, $g(t)$, from time $t_{1}$ to time $t_{2}$, divided by $t_{2}-t_{1}$, i.e.

$$
\bar{L}=\left(t_{2}-t_{1}\right)^{-1} \int_{t_{1}}^{t_{2}} g(t) d t
$$

The midpoint of the length range was used for species for which there were no available growth curves.

Egg wet weight was taken from the equation for the volume of a sphere,

$$
W=1 / 3 \pi r^{3} \rho,
$$

where $r=$ the average radius of the egg $(\mathrm{cm}) ; \rho=$ the specific gravity of the eggs $\left(1 \mathrm{~g} \mathrm{~cm}^{-3}\right)$. Egg radii were taken from the author or from Bagenal (1971), Russell (1976), and Theilacker \& Dorsey (1980).

Estimates of Lloyd's patchiness index came from 3 sources: (1) values reported by the authors, e.g. Smith (1973), Hewitt (1981), Koslow et al. (1985), and McGurk (1986); (2) values calculated from densitiesat-station data reported by the authors, e.g. Sette (1943), Conand \& Fagetti (1971), Crossland (1980), Berrien et al. (1981), Anderson (1984), and Chavance et al. (1984), or (3) values calculated from catch statistics such as the coefficient of variation of the catches reported by Harding \& Talbot (1973). All estimates of patchiness were extracted from the same body of data that were used to calculate mortality rates. The patchiness or density-at-station data were reported for either a series of sampling cruises (Sette 1943, Conand \& Fagetti 1971, Harding \& Talbot 1973, Crossland 1980, Berrien et al. 1981, Anderson 1984, Chavance et al. 1984, McGurk 1986), or for a range of ages of the eggs or larvae (Smith 1973, Hewitt 1981, Koslow et al. 1985). The calculation of patchiness for density-at-station data was as follows: (1) a mean density, a variance, and a single patchiness index were calculated for each cruise; (2) each value of patchiness was $\log _{e}$-transformed, because patchiness is log-normally distributed for many of the species for which it has been measured, and was then weighted by the total number of samples used to estimate it, because the accuracy of a statistic increases with the number of samples used to calculate it; and (3) a mean ( $\pm 1 \mathrm{SD}$ ) patchiness value was calculated from the weighted $\log _{e}$ (patchiness) values for the series of cruises. The patchiness values reported for a range of ages had to be adjusted so that they were

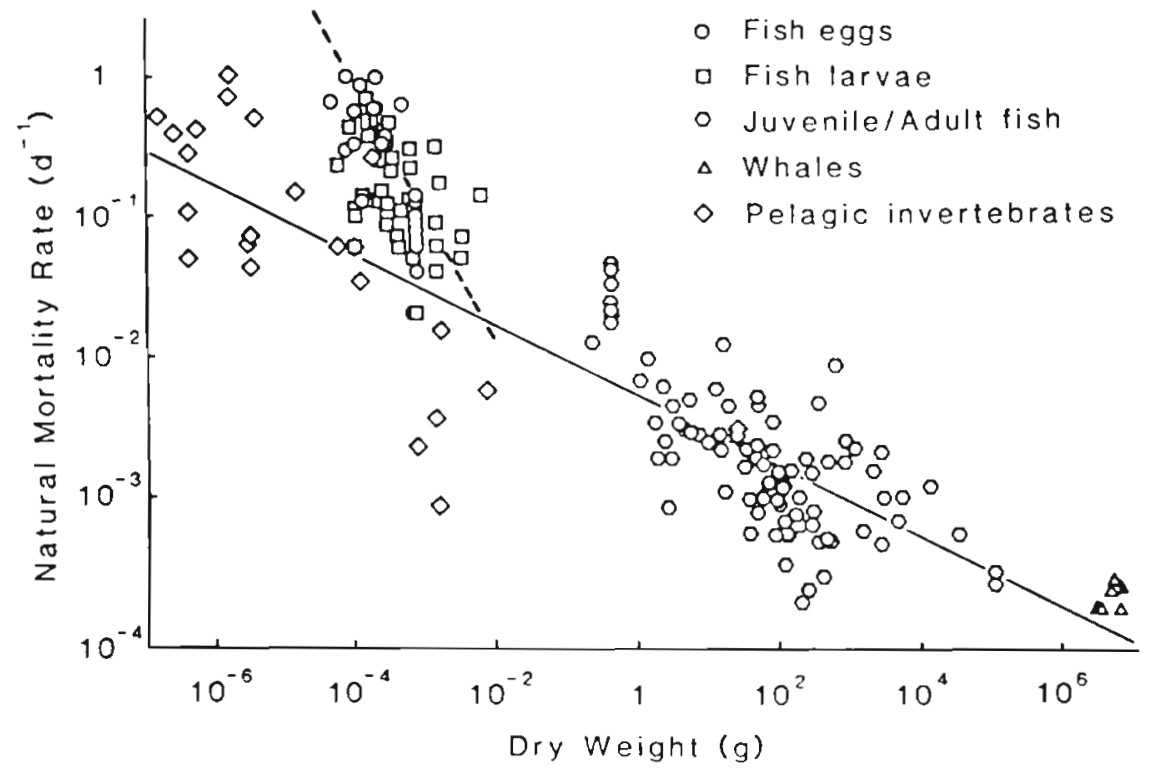

Fig. 1. Plot of instantaneous daily natural mortality rates on dry weight for marine organisms. See Table 1 and Appendix 1 for sources of data. Solid line is the mortality rate predicted by Peterson \& Wroblewski's (1984) model: $M_{w}=5.26 \times 10^{-3}$ $W^{-0.25}$ Broken line is the linear regression of $\log _{e} M$ on $\log _{e} W$ for fish eggs and larvae: $M=2.2 \times 10^{-4}$ $W^{-085}(\mathrm{n}=74, \mathrm{r}=0.58, \quad P<0.001$ $\left.S E_{\mathrm{q}}=0.08\right)$ 
comparable to those calculated directly from densityat-station data. This was done by: (1) using the reported mortality rates to calculate the relative number of eggs or larvae that were present at each age; (2) weighting each $\log _{e}$-transformed value of patchiness-at-age by the relative number of individuals at that age; and (3) calculating a mean ( \pm 1 SD) patchiness value from the weighted log (patchiness-atage) values. This procedure gives patchiness values that are correlated to some small degree with the observed field mortality rates. Therefore, caution was exercised in employing these data.

Sampling scale was measured with 2 variables: (1) the average volume of water filtered by one tow of the plankton net; and (2) the average area surrounded by a single sampling station. This latter variable corresponds to Lloyd's (1967) definition of a quadrat. I assumed that all surveys were performed over a uniform grid of stations. The total survey area was estimated from maps reported by the authors and then divided by the total number of sampling stations to give the average area of the quadrat surrounding a single station.

All linear regressions reported in this paper are of the functional, rather than predictive, type because of all the variables were measured with error. In such cases the functional regression provides the best estimate of the central tendency of the relation (Ricker 1973).

\section{RESULTS}

\section{Natural mortality and dry weight}

The plot of natural mortality rates on dry weight (Fig. 1) shows that the mortality rates predicted by Peterson \& Wroblewski's (1984) model provide an excellent overall fit to the data for pelagic invertebrates, juvenile and adult fish, and whales, over a weight range of 14 orders of magnitude. The plot also shows that: (1) their model consistently underestimates the mortality rates within the fish eggs and larvae group; (2) these rates are 5 to 10 times higher than those predicted from their dry weight; and (3) the weight exponent of the mortality rate for fish eggs and larvae is more than 3 times higher than $-1 / 4$. The relation estimated by the linear regression of $\log _{\mathrm{e}} M$ on $\log _{\mathrm{e}} W$ for fish eggs and larvae is

$M=2.2 \times 10^{-4} W^{-0.85} ; \mathrm{n}=74 ; \mathrm{r}=0.58 ; P<0.001 ;$

$$
S E_{v}=0.08 \text {, }
$$

where $S E_{v}=$ the standard error of the slope, $v$. These 3 observations suggest that a variable additional to dry weight is involved in determining the natural mortality rates of marine pelagic fish eggs and larvae. The hidden variable, $H$, must be equal to the ratio of the observed mortality rate as summarized by Eqn (7) to that predicted by Eqn (2), or

$$
H=4.18 \times 10^{-2} W^{-0.60} \text {. }
$$

\section{Patchiness of fish eggs and larvae}

The patchiness of marine pelagic fish eggs and larvae is generally log-normally distributed within a species (Fig. 2). Therefore, the geometric mean is the appropriate statistic of the central tendency of patchiness (Table 1). A plot of mean patchiness on dry weight (Fig. 3) demonstrates that patchiness is an excellent

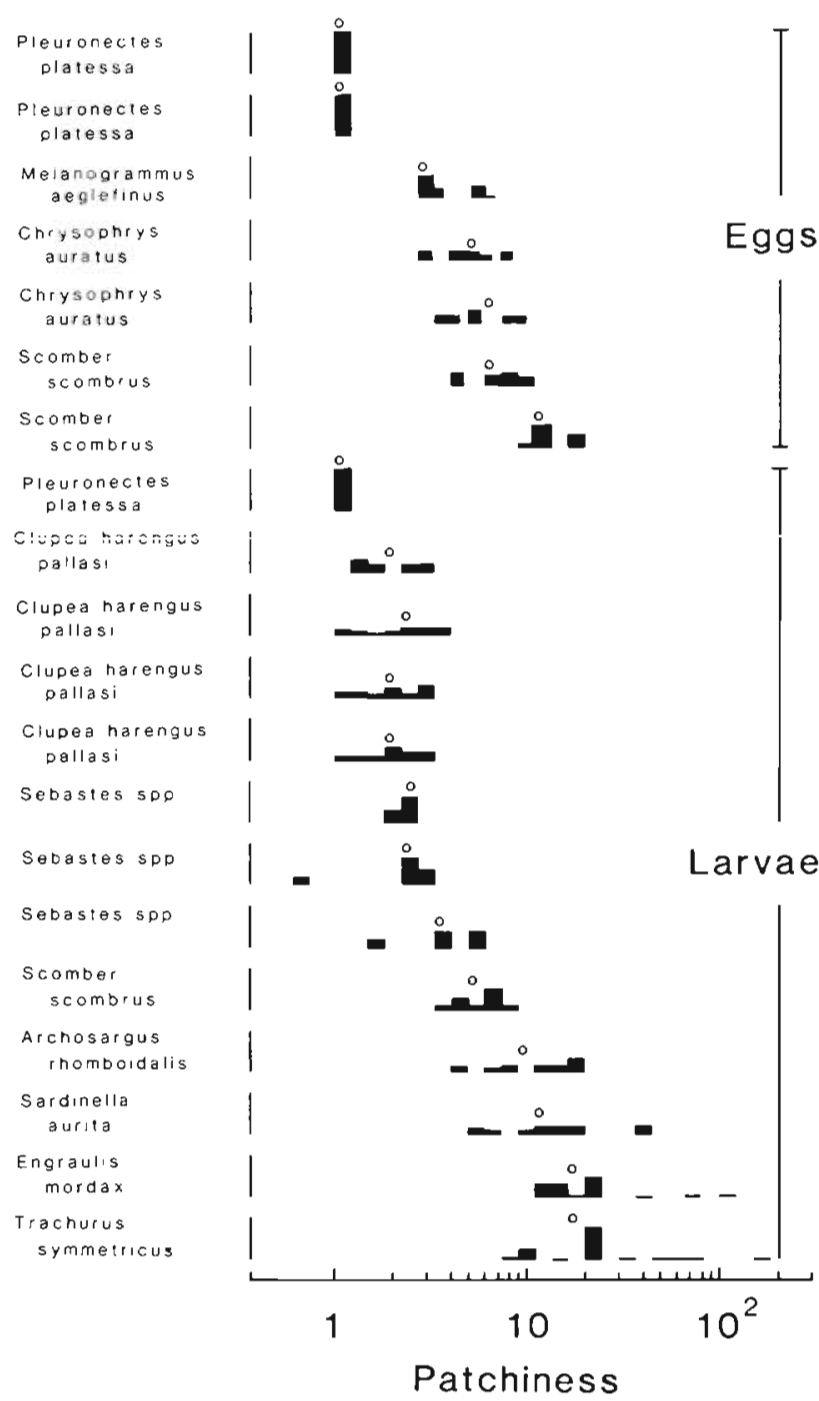

Fig. 2. Frequency distribution of sample-weighted $\log _{e}$-transformed Lloyd's patchiness index for 10 species of marine pelagic fish eggs and larvae. Vertical axes range from 0.0 to 1.0. Empty circles indicate mean $\log _{e}$ (patchiness) 
candidate for the hidden variable, $H$; the mean patchiness values of the eggs of 5 species of fish and the larvae of 8 species of fish fall symmetrically about the line described by Eqn (8). The linear regression of $\log _{e}$ (mean patchiness) on $\log _{e} W$ has a slope $( \pm 1 \mathrm{SE})$ of $-0.79( \pm 0.15) ;$ the slope $( \pm 1 \mathrm{SE}$ ) for the regression using only patchiness-cruise data is $-0.71( \pm 0.14)$. Although both the slopes and the intercepts are higher than those of Eqn (8), the fit of the patchiness data is good considering the error involved in measuring both patchiness and dry weight.

In order to determine if the scale of sampling has an effect on patchiness 2 indices of sampling scale were

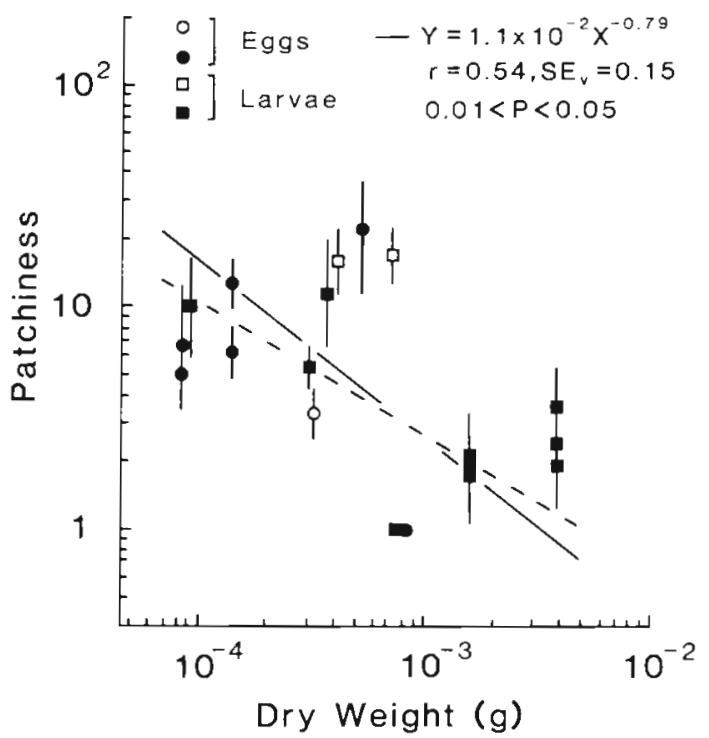

Fig. 3. Linear regression of mean $\log _{e}$ (patchiness) on $\log _{e}$ (dry weight) for marine pelagic fish eggs and larvae. Vertical bars indicate \pm 1 standard deviation of mean $\log _{e}$ (patchiness). Broken line is the predicted line for the hidden variable, $H$. Open symbols are patchiness values from patchiness-at-age data; closed symbols are values from patchiness-cruise data

devised: (1) the average volume of water filtered in one plankton-net tow; and (2) the average area per sampling station. Unfortunately, the volume of water filtered was reported for only 7 of the 13 species listed in Table 1. In the other 6 species it was replaced with numbers of eggs or larvae $\mathrm{m}^{-2}$ surface area or numbers $\mathrm{m}^{-2} \mathrm{~d}^{-1}$. The information required to convert one set of numbers to another was not reported. Therefore, the residuals of the patchiness-weight regression were plotted on area per station. They were positively and significantly $(0.001<P<0.005)$ correlated with area per station but this correlation depended totally on the area per station of the 3 species sampled by the CalCOFI ichthyoplankton survey grid off southern California (Ahlstrom 1966): Sardinops sagaz eggs, and Engraulis mordax and Trachurus symmetricus larvae.

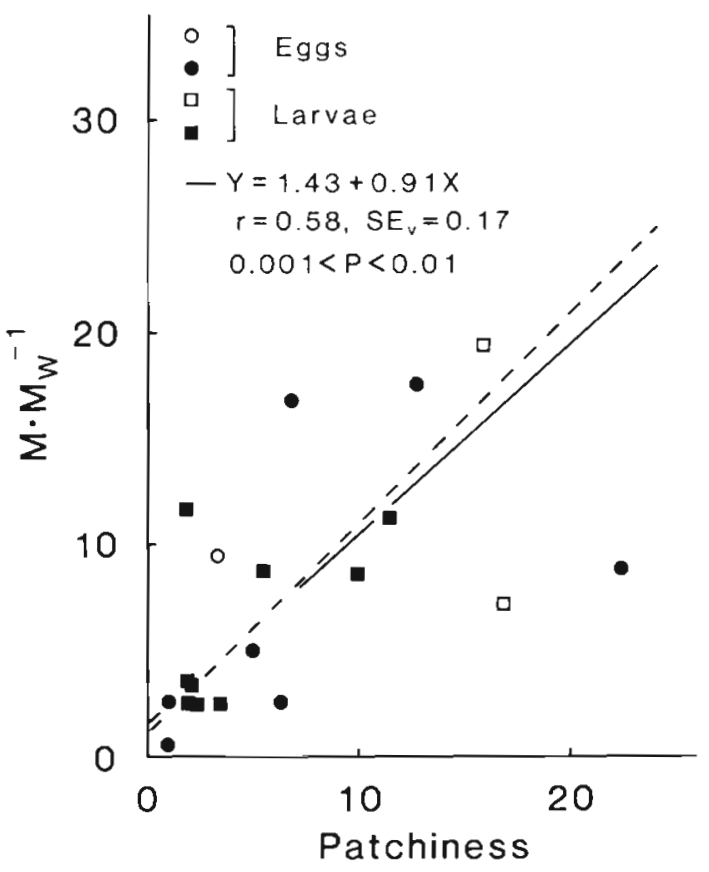

Fig. 4. Linear regression of the ratio of observed mortality, $M$, to the rate predicted by Peterson \& Wroblewski's (1984) model $M_{w}$ on Lloyd's patchiness index. Broken line is predicted from Eqn (6): $M \cdot M_{w}=1+p_{1}$. Open symbols are patchiness values calculated from patchiness-at-age data; closed symbols from patchiness-cruise data

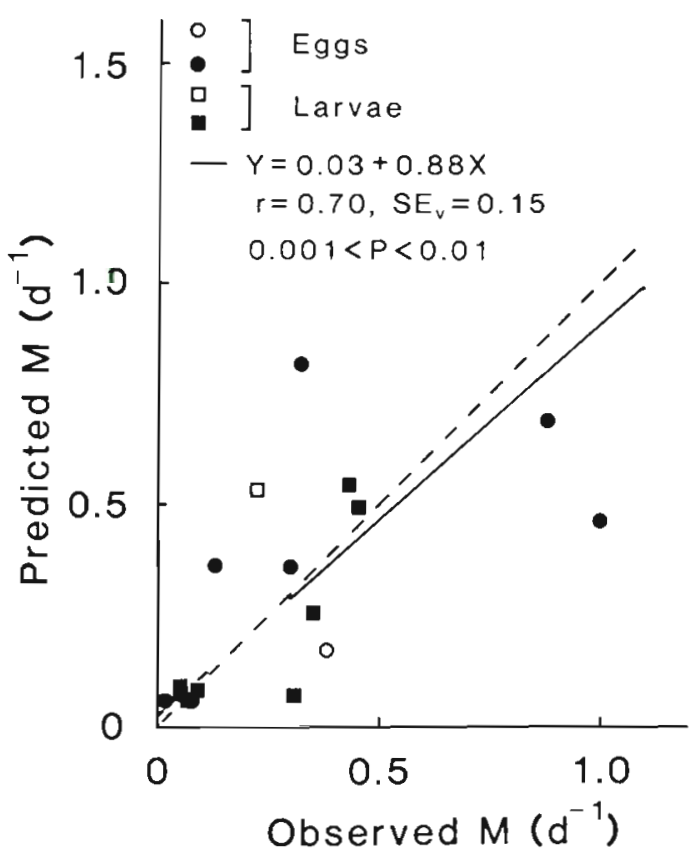

Fig. 5. Linear regression of mortality rates predicted by the mortality-patchiness model, $M=5.26 \times 10^{-3} W^{-0.25}\left(1+p_{1}\right)$, on observed field mortality rates. Broken line is the line of equality between predicted and observed. Open symbols are patchiness values calculated from patchiness-at-age data; closed symbols are values from patchiness-cruise data 
When these species were removed the correlation was not significant $(P>0.05)$. Since: $(1)$ two of these $3 \mathrm{Cal}-$ COFI data points were derived from patchiness-at-age data, which is considered less trustworthy than patchiness-cruise data; (2) there was no relation between the residuals and area per station over the range 0 to 2050 $\mathrm{km}^{2}$; and (3) there is no other evidence to support the hypothesis that patchiness increases with increasing quadrat size, but theoretical arguments that support the opposite, patchiness was not corrected for the effects of sampling scale.

\section{Patchiness-mortality interaction}

A plot of the ratio of the observed field mortality rates to that predicted by Eqn (2) on mean patchiness shows that the 2 variables are highly correlated (Fig. 4). This correlation remains after the 3 patchinessat-age data points are removed, although the level of significance falls to $0.01<P<0.05$. The slope and the intercept of the regression are indistinguishable from 1.0, which supports the theoretical arguments that the hidden variable is equal to $1+$ patchiness. When the mortality rate predicted by Eqn (6) is plotted against the observed field mortality rates (Fig. 5), the data points fall symmetrically about the line of equality. A linear regression of predicted on observed mortality rate has a slope that is within 1 standard error of the line of equality and an intercept that is indistinguishable from zero. These results are unchanged when the 3 patchiness-at-age data points are removed. In summary, the evidence supports the hypothesis that the mortality rates of marine pelagic fish eggs and larvae vary directly with their spatial patchiness as measured by $1+$ Lloyd's patchiness index.

\section{DISCUSSION}

Powerful ideas generate new questions as well as answer old ones. The allometric approach to studying ecosystem processes has produced a simple model of the weight-dependence of mortality rate in the pelagic ecosystem. It has also generated a new question: why are the mortality rates of marine pelagic fish eggs and larvae so much higher than those predicted by this general trend line? This observation is what SchmidtNielsen (1984) calls a 'secondary signal'. I propose one possible answer: the mortality rate for this group of animals is directly proportional to their spatial patchiness. This hypothesis has biological meaning that is rooted in the idea that fish embryos and early stage larvae are more vulnerable to predators than they would otherwise be on the basis of their body weight.
Their vulnerability implies that the feeding rate of their predators is limited more by the time required to locate them than by the time required to capture and consume them. Thus the spatial distribution of fish eggs and larvae determines how often a predator encounters a patch of eggs or larvae and how intense is the predation mortality on a patch.

Peterson \& Wroblewski's (1984) premise, that natural mortality rate scales as the -0.25 power of dry weight, was derived from data on juvenile and adult fish only, but it also happens to describe well the overall trend of mortality rate with dry weight for organisms other than adult fish. It also happens to be the exponent for the weight-dependence of specific metabolic rate (metabolic rate per unit weight). Therefore, it was used in this paper as a convenient description of the first-order scaling of natural mortality rate. In this argument, patchiness is considered to be a second-order scaling. I recognize that the weight exponent of mortality rate may be quite different from -0.25 for groups other than fishes. It is possible that the profound differences in the mass exponent and scaling coefficient of the production/biomass $(\mathrm{P} / \mathrm{B})$ ratios between invertebrates, fishes, and mammals that were demonstrated by Banse \& Mosher (1980) have counterparts in the weight exponents of natural mortality rate. In a steadystate system the $\mathrm{P} / \mathrm{B}$ ratio is equivalent to natural mortality rate because it is that fraction of the production which is excess to the requirements of maintaining a steady-state biomass and which is lost to predation. The question of the correct numerical weight exponent of mortality rates is still an open one; it can be answered by: (1) evaluating the parameters of Peterson \& Wroblewski's Eqn (6), $M_{w}=c k W^{-x}$, for organisms other than fish; (2) by filling the gaps in the mortalityweight plot, particularly the gap between $10^{-2}$ and $1 \mathrm{~g}$ and the very large gap between $10^{-10}$ and $10^{-6} \mathrm{~g}$; and (3) by devising and testing second-order ecological hypotheses to account for any between-group differences in the weight exponent. However, even if it can be demonstrated that the overall weight exponent is not -0.25 , this does not affect the core of the mortalitypatchiness hypothesis. There is a real correlation between natural mortality and spatial patchiness in pelagic fish eggs and larvae and there are logical arguments to support the idea that this correlation is causal in nature.

The mortality-patchiness hypothesis is a significant improvement over Peterson \& Wroblewski's (1984) model; $_{i}$ it reduces the deviation between model and observation from a factor of +5 to 10 to a factor of \pm 1 . The fit of the field mortality rates to the model is excellent for those species whose eggs and larvae experience mortality rates less than $0.1 \mathrm{~d}^{-1}$ : Pleuronectes platessa eggs and larvae, Clupea harengus 
pallasi larvae, and Sebastes spp. larvae. The fit is less good for those with higher mortality rates. One reason for the relatively poor fit of the latter group is real variation in time and space of both mortality and patchiness

In this analysis natural mortality rates are assumed to be constant over the egg and larval stages even though it is obvious that over longer time periods mortality must decrease in order to approach the lower values that have been measured for juvenile and adult fish. The assumption of constant mortality rate has been commonly used in larval fish ecology and it is supported by the fact that the catch curves of most fish eggs and larvae are relatively straight (May 1974 Dahlberg 1979). This assumption is probably reasonable for those species which fall on the low mortality/ low patchiness end of the mortality-patchiness continuum, but it is probably not an accurate assumption for those species in the high mortality/high patchiness group. An example of the former is Pacific herring Clupea harengus pallasi; the larvae lose 2.5 patchiness points over a $25 \mathrm{~d}$ period before they begin to school (McGurk 1986). According to the mortality-patchiness hypothesis this implies a 2.5 -fold decrease in larval mortality rate over this period, a decrease which is probably within the range of observational error; the catch curves measured for all populations of larval Pacific herring have been straight (McGurk 1984, 1986). An example of the latter group is the jack mackerel Trachurus symmetricus, which loses 12 patchiness points in $4 \mathrm{~d}$ of early larval life (Hewitt 1981). Hewitt et al. (1985) reported that the mortality rate of larval jack mackerel off southern California decreases from $1.37 \mathrm{~d}^{-1}$ at hatch to $0.18 \mathrm{~d}^{-1} 30 \mathrm{~d}$ later (Table 1), a 7.6 -fold decrease. The eggs of the Pacific sardine Sardinops sagax lose about 50 patchiness points in $3 \mathrm{~d}$ (Smith 1973), indicating that the mortality rate should decrease 50 -fold during the egg stage. This rapid change in mortality rate may not be measurable with current sampling and egg-aging techniques. At the very least, it suggests that the estimate of $M=$ $0.31 \mathrm{~d}^{-1}$ (Table 1) for Pacific sardine eggs is too low.

Mortality rates have been assumed to operate uniformly in space but there is evidence to indicate that mortality varies spatially as well as temporally. Irreversibly starving larvae have been found to be patchily distributed by Shelbourne (1957: Pleuronectes platessa), O'Connell (1980: Engraulis mordax), Hewitt et al. (1985: Trachurus symmetricus), and McGurk (1986: Clupea harengus pallasi). The role of irreversible starvation has been ignored in this analysis because there is no agreement on how the instantaneous rate of mortality due to starvation is to be calculated, and therefore, there is no agreement on its relative importance to total mortality. The evidence to date indicates that starvation occurs in nature but that it is responsible for only 3 to $25 \%$ of total mortality (McGurk 1986). Eqn (6) can be easily modified to accept an additive term for starvation mortality. This subject deserves further investigation.

Spatial patchiness also changes with time and space. It changes with age as eggs disperse from their spawning sites and as larvae develop schooling behaviour (Hewitt 1981, Koslow et al. 1985, McGurk 1986). Therefore, the patchiness indices calculated from ichthyoplankton sample data are influenced by the daily rate of production of eggs and larvae, the daily rate of mortality, and the age structure of the population. Despite theoretical argument to the contrary, it is entirely reasonable to suppose that there is a relationship between patchiness and sampling scale. The nature of the relationship, if it exists, is entirely unknown; it deserves more investigation.

The success of Eqn (6) in predicting the mortality rates of fish eggs and larvae in the sea has implications for the study of reproductive strategies in marine fishes, and for the study of the recruitment process. Those species which release eggs in a highly patchy pattern, e.g. Pacific sardine, experience relatively high egg and larval mortality rates. I speculate that there are advantages to patchy egg release that offset the losses due to predation. One possible advantage is predator avoidance by the spawning adults. A comprehensive theory of reproductive strategies in fishes must combine hypotheses of egg release in space with hypotheses of egg release in time (Lambert \& Ware 1984).

The model implies that turbulent mixing of the upper sea due to storms, upwelling events, and tides would promote dispersal of eggs and larvae and thereby decrease predation mortality, while stratification of the water would tend to retard dispersal and so increase predation mortality. Lasker (1985) has proposed that stratification would tend to promote survival in larval fishes by allowing the formation of patches of food organisms with sufficient density to promote successful first-feeding. The optimal environment for larval survival may be a balance between high densities of aggregated food organisms and low densities of well-dispersed larvae. Such an environment occurs whenever dispersing larvae drift into a front between 2 water masses where mixing is vigorous and biological production is high. These fronts are presumed to define and surround larval fish retention zones (Iles \& Sinclair 1982).

The patchiness-mortality hypothesis described in this paper can be generalized to any predator-prey system where handling time can be considered a relatively small quantity. One system of obvious practical importance is predation by man on schooling pelagic 
fishes. For such fisheries the limiting step is the time required to locate a school, not the time required to handle it. For example, once a purse-seine vessel has located a school of herring and manoevered its gear into the school it can often capture a large proportion of the school. It is reasonable to speculate that the instantaneous rate of fishing mortality is proportional to the spatial patchiness of the herring. Since fishing mortality is equal to the product of the catchability coefficient and fishing effort, this implies that the catchability coefficient is directly proportional to the spatial patchiness of the fish. It also implies that management policies that involve restricting the areal extent of a fishery may be biasing the catchability of the fleet and the fishing mortality that it exerts on the stock. This generalization of the mortality-patchiness hypothesis and others have yet to be tested.

Acknowledgements. Earlier versions of this paper were read and commented upon by N. J. Wilimovsky, D. Hay, K. Banse, L. M. Dickie, and one anonymous referee.

Appendix. Natural mortality rates and dry weights for marine organisms. Species are listed in alphabetical order within their group. Populations of fish eggs and larvae for which estimates of spatial patchiness were available are listed in Table 1

\begin{tabular}{|c|c|c|c|c|}
\hline Species & Area & $M\left(d^{-1}\right)$ & $W(g)$ & Source \\
\hline \multicolumn{5}{|l|}{ Pelagic invertebrates } \\
\hline Acartia hudsonii & Narragansett Bay & $6.3 \times 10^{-2}$ & $3.1 \times 10^{-6}$ & Durbin \& Durbin (1981) \\
\hline \multirow[t]{2}{*}{ Acartia tonsa } & Chesapeake Bay & $7.0 \times 10^{-1}$ & $1.6 \times 10^{-6}$ & Heinle (1966) \\
\hline & & $5.0 \times 10^{-1}$ & $3.9 \times 10^{-6}$ & \\
\hline \multirow[t]{2}{*}{ Euphausia pacifica } & California coast & $6.1 \times 10^{-2}$ & $1.1 \times 10^{-4}$ & Brinton (1976), Lindley (1978) \\
\hline & & $1.5 \times 10^{-2}$ & $1.9 \times 10^{-3}$ & \\
\hline \multirow[t]{8}{*}{ Eurytemora affinus } & Patuxent River, Maryland & $5.0 \times 10^{-2}$ & $4.2 \times 10^{-7}$ & Heinle \& Flemer (1975) \\
\hline & & $1.1 \times 10^{-1}$ & $4.2 \times 10^{-7}$ & \\
\hline & & $2.8 \times 10^{-1}$ & $3.8 \times 10^{-7}$ & \\
\hline & & $3.9 \times 10^{-1}$ & $2.5 \times 10^{-7}$ & \\
\hline & & $4.3 \times 10^{-2}$ & $3.3 \times 10^{-6}$ & \\
\hline & & $7.4 \times 10^{-2}$ & $3.3 \times 10^{n}$ & \\
\hline & & $7.2 \times 10^{-2}$ & $3.3 \times 10^{i i}$ & \\
\hline & & 1.1 & $1.6 \times 10^{-6}$ & \\
\hline Illex illecebrosus & Scotian Shelf & $2.9 \times 10^{-3}$ & $3.2 \times 10^{1}$ & $\begin{array}{l}\text { Amaratunga et al. (1978), } \\
\text { Hurley \& Mohn (1978) }\end{array}$ \\
\hline Paracalanidae spp. & Kaneohe Bay, Hawaii & $5.2 \times 10^{-7}$ & $1.5 \times 10^{-7}$ & Newbury \& Bartholemew (1976) \\
\hline Pleurobrachia brachei & La Jolla Bight & $2.6 \times 10^{-1}$ & $20 \times 10^{4}$ & Hirota $(1974)$ \\
\hline \multirow[t]{2}{*}{ Thysanoessa inermis } & North Sea & $1.5 \times 10^{-1}$ & $1.5 \times 10^{-5}$ & Lindley \& Williams (1980), \\
\hline & & $2.3 \times 10^{-3}$ & $8.1 \times 10^{4}$ & Lindley (1980) \\
\hline Thysanoessa longicaudata & North Atlantic & $6.0 \times 10^{-2}$ & $8.1 \times 10^{-4}$ & Lindley $(1978)$ \\
\hline \multirow[t]{4}{*}{ Thysanoessa raschi } & Gulf of St. Lawrence & $3.4 \times 10^{-2}$ & $1.3 \times 10^{-4}$ & Berkes (1977) \\
\hline & & $5.7 \times 10^{-3}$ & $8.2 \times 10^{3}$ & \\
\hline & North Sea & $3.6 \times 10^{-3}$ & $1.5 \times 10^{-3}$ & Lindley $(1978,1980)$ \\
\hline & NW Atlantic & $8.6 \times 10^{-4}$ & $1.7 \times 10^{-3}$ & \\
\hline \multicolumn{5}{|l|}{ Fish eggs } \\
\hline Engraulis anchoita & N Argentine coast & $6.0 \times 10^{-1}$ & $1.1 \times 10^{-4}$ & Clechomski \& Capezzani (1973) \\
\hline Engraulis japonica & Japan coast & $3.3 \times 10^{-1}$ & $1.1 \times 10^{-4}$ & Hiyashi (1966) \\
\hline Melanogrammus aeglefinus & Faroe Islands & $1.0 \times 10^{-1}$ & $3.2 \times 10^{-4}$ & Saville (1956) \\
\hline \multirow[t]{10}{*}{ Pleuronectes platessa } & English Channel & $4.0 \times 10^{-2}$ & $8.4 \times 10^{-4}$ & Harding et al. (1978) \\
\hline & & $1.4 \times 10^{-1}$ & $8.4 \times 10^{-4}$ & \\
\hline & & $9.0 \times 10^{-2}$ & $8.4 \times 10^{-4}$ & \\
\hline & & $7.0 \times 10^{-2}$ & $8.4 \times 10^{-4}$ & \\
\hline & & $6.0 \times 10^{-2}$ & $8.4 \times 10^{-4}$ & \\
\hline & & $1.0 \times 10^{-1}$ & $8.4 \times 10^{-4}$ & \\
\hline & & $1.1 \times 10^{-1}$ & $8.4 \times 10^{-4}$ & \\
\hline & & $8.0 \times 10^{-2}$ & $8.4 \times 10^{-4}$ & \\
\hline & & $1.3 \times 10^{-1}$ & $8.4 \times 10^{-4}$ & \\
\hline & Irish Sea & $1.0 \times 10^{-1}$ & $8.4 \times 10^{-4}$ & Harding \& Talbot (1973) \\
\hline Sardinops melanostica & Kyushu Is., Japan & $3.3 \times 10^{-1}$ & $2.8 \times 10^{-4}$ & Nakai \& Hattori (1962) \\
\hline \multirow[t]{4}{*}{ Scomber scombrus } & St. Georges Bay, Nova Scotia & $5.6 \times 10^{-1}$ & $1.6 \times 10^{-4}$ & Ware \& Lambert (1985) \\
\hline & & $4.0 \times 10^{-1}$ & $1.6 \times 10^{-4}$ & \\
\hline & & $5.2 \times 10^{-1}$ & $1.6 \times 10^{-4}$ & \\
\hline & & $4.1 \times 10^{-1}$ & $1.6 \times 10^{-4}$ & \\
\hline \multirow[t]{2}{*}{ Solea solea } & R Blackwater estuary, England & $6.0 \times 10^{-1}$ & $2.3 \times 10^{-4}$ & Riley (1974) \\
\hline & $E$ coast England & 1.0 & $2.3 \times 10^{-4}$ & \\
\hline Tautogolabrus adspersus & Long Is. Sound & $6.7 \times 10^{-1}$ & $5.0 \times 10^{-5}$ & Williams \& Williams (1973) \\
\hline Trachurus symmetricus & S Calitornia coast & $5.8 \times 10^{-1}$ & $1.4 \times 10^{-4}$ & Farris $(1961)$ \\
\hline
\end{tabular}


Appendix (continued)

\begin{tabular}{|c|c|c|c|c|}
\hline Species & Area & $M\left(d^{-i}\right)$ & $W(g)$ & Source \\
\hline \multicolumn{5}{|l|}{ Fish larvae } \\
\hline \multirow{7}{*}{ Clupea harengus harengus } & Bay of Fundy, Nova Scotia & $1.0 \times 10^{-1}$ & $1.1 \times 10^{-4}$ & Das (1968), Laurence (1979) \\
\hline & & $6.0 \times 10^{-2}$ & $\begin{array}{l}1.1 \times 10^{-4} \\
1.1 \times 10^{-4}\end{array}$ & \\
\hline & Norwegian coast & $1.4 \times 10^{-1}$ & $1.4 \times 10^{-4}$ & $\begin{array}{l}\text { Dragesund \& Nakken (1971a), } \\
\text { Laurence (1979) }\end{array}$ \\
\hline & & $4.6 \times 10^{-1}$ & $1.4 \times 10^{-4}$ & $\begin{array}{l}\text { Dragesund \& Nakken (1971b), } \\
\text { Laurence }(1979)\end{array}$ \\
\hline & Georges Bank & $4.0 \times 10^{-2}$ & $1.6 \times 10^{-3}$ & $\begin{array}{l}\text { Laurence (1979), } \\
\text { Lough et al. (1981) }\end{array}$ \\
\hline & R Blackwater estuary, England & $6.0 \times 10^{-2}$ & $4.6 \times 10^{-4}$ & Henderson et al. (1984), \\
\hline & & $7.0 \times 10^{-2}$ & $4.6 \times 10^{-4}$ & Laurence (1979) \\
\hline \multirow[t]{4}{*}{ Clupea harengus pallasi } & Barkley Sound, British Columbia & $4.1 \times 10^{-1}$ & $3.0 \times 10^{-4}$ & Stevenson (1962), McGurk (1986) \\
\hline & Queen Cove, Vancouver Is. & $2.5 \times 10^{-1}$ & $3.0 \times 10^{-4}$ & \\
\hline & Akkeshi Bay, Japan & $9.0 \times 10^{-2}$ & $3.3 \times 10^{-4}$ & Iizuka (1966), McGurk (1986) \\
\hline & & $1.2 \times 10^{-1}$ & $3.3 \times 10^{-4}$ & \\
\hline Engraulis japonica & W coast Japan & $3.0 \times 10^{-1}$ & $7.0 \times 10^{-4}$ & $\begin{array}{l}\text { Hiyashi (1966), } \\
\text { Zweifel \& Lasker (1976) }\end{array}$ \\
\hline \multirow{2}{*}{ Etrumeus teres } & E Gulf of Mexico & $1.3 \times 10^{-1}$ & $2.7 \times 10^{-4}$ & Houde $(1977 a)$ \\
\hline & & $1.3 \times 10^{-1}$ & $2.2 \times 10^{-4}$ & \\
\hline Harengula jaguana & E Gulf of Mexica & $2.8 \times 10^{-1}$ & $3.0 \times 10^{-4}$ & Houde $(1977 \mathrm{c})$ \\
\hline Melanogrammus aeglefinus & North Sea & $1.1 \times 10^{-1}$ & $4.9 \times 10^{-4}$ & Jones (1973), Laurence (1979) \\
\hline Micromesistius poutassou & Rockall Bank, NE Atlantic & $1.5 \times 10^{-1}$ & $2.7 \times 10^{-4}$ & Bailey (1974), Laurence (1979) \\
\hline \multirow{2}{*}{ Opisthonema oglinum } & E Gulf of Mexico & $2.1 \times 10^{-1}$ & $3.7 \times 10^{-4}$ & Houde $(1977 \mathrm{~b})$ \\
\hline & & $2.6 \times 10^{1}$ & $3.7 \times 10^{-4}$ & \\
\hline \multirow[t]{2}{*}{ Pleuronectes platessa } & English Channel & $6.0 \times 10^{-2}$ & $7.5 \times 10^{-4}$ & $\begin{array}{l}\text { Bannister et al. (1974), } \\
\text { Ryland (1966) }\end{array}$ \\
\hline & & $2.0 \times 10^{-2}$ & $7.5 \times 10^{-4}$ & \\
\hline Pseudopleuronectes americanus & Mystic R, Connecticut & $2.3 \times 10^{-1}$ & $6.0 \times 10^{-5}$ & Pearcy $(1962 a, b)$ \\
\hline Sardinops melanostica & S Japan coast & $1.3 \times 10^{-1}$ & $7.0 \times 10^{-4}$ & $\begin{array}{l}\text { Nakai \& Hattori (1962), } \\
\text { Zweifel \& Lasker }(1976)\end{array}$ \\
\hline Sardinops sagax & S California coast & $1.0 \times 10^{-1}$ & $1.8 \times 10^{-3}$ & $\begin{array}{l}\text { Lenarz (1973), } \\
\text { Zweifel \& Lasker (1976) }\end{array}$ \\
\hline Scomber japonicus & Japan coast & $1.4 \times 10^{-1}$ & $7.0 \times 10^{-3}$ & $\begin{array}{l}\text { Watanabe (1970), } \\
\text { Ware \& Lambert (1985) }\end{array}$ \\
\hline \multirow[t]{3}{*}{ Scomber scombrus } & St. Georges Bay, Nova Scotia & $3.8 \times 10^{-1}$ & $1.7 \times 10^{-4}$ & Ware \& Lambert (1985) \\
\hline & & $6.9 \times 10^{-1}$ & $1.7 \times 10^{-4}$ & \\
\hline & & $4.8 \times 10^{-1}$ & $1.7 \times 10^{-4}$ & \\
\hline \multicolumn{5}{|l|}{ Juvenile and adult fishes } \\
\hline Ammodytes tobianus & SE English coast & $3.3 \times 10^{-3}$ & 1.9 & Reay (1973) \\
\hline Argentina silus & Nova Scotia banks & $7.7 \times 10^{4}$ & $5.0 \times 10^{1}$ & Zukowski (1972) \\
\hline Argyrosomus argentatus & E China and Yellow Seas & $1.9 \times 10^{-3}$ & $5.1 \times 10^{1}$ & Mako (1961) \\
\hline Blennius pholis & Menai Straits, Wales & $2.5 \times 10^{-3}$ & 2.6 & Qasim (1957) \\
\hline Brevoortia tyrannus & Chesapeake Bay & $1.0 \times 10$ & $7.5 \times 10^{1}$ & Schaaf \& Huntsman (1972) \\
\hline Cephalopholis fulva & S Jamaican Shelf & $1.5 \times 10^{-4}$ & $1.1 \times 10^{2}$ & Thompson \& Munro (1978) \\
\hline Cetengraulis mysticetus & Gulf of Panama & $5.8 \times 10^{-3}$ & $1.4 \times 10^{1}$ & Bayliff $(1966)$ \\
\hline Cheilodactylus macropterus & Chatham Is., New Zealand & $2.2 \times 10^{4}$ & $2.6 \times 10^{2}$ & Vooren $(1977)$ \\
\hline \multirow[t]{4}{*}{ Clupea harengus harengus } & Celtic Sea & $5.5 \times 10^{-4}$ & $4.2 \times 10^{1}$ & Burd \& Bracken (1965) \\
\hline & S North Sea & $5.5 \times 10^{-4}$ & $4.0 \times 10^{1}$ & Cushing \& Bridger $(1966)$ \\
\hline & Lusterfjord, Norway & $2.1 \times 10^{-3}$ & $1.6 \times 10^{1}$ & Aasen (1952) \\
\hline & N Norway Sea & $9.4 \times 10^{-3}$ & 1.5 & Dragesund $(1970)$ \\
\hline Colabis saira & NE Pacific & $4.4 \times 10^{3}$ & $2.1 \times 10^{1}$ & Hughes (1974) \\
\hline Cynoscion nebulosus & SW Florida coast & $1.2 \times 10^{-3}$ & $9.1 \times 10^{1}$ & Iverson \& Moffet (1962) \\
\hline Cynoscion nobilis & California coast & $8.3 \times 10^{-4}$ & $2.9 \times 10^{3}$ & Thomas (1968) \\
\hline \multirow{2}{*}{ Eopsetta jordani } & British Columbia coast & $6.9 \times 10^{-4}$ & $4.9 \times 10^{3}$ & Ketchen \& Forrester (1966) \\
\hline & & $5.5 \times 10^{-4}$ & $3.6 \times 10^{4}$ & \\
\hline Epinephelus guttatus & S Jamaican Shelf & $1.9 \times 10^{-3}$ & $2.6 \times 10^{2}$ & Thompson \& Munro (1978) \\
\hline Epinephelus striatus & S Jamaican Shelf & $5.8 \times 10^{-4}$ & $1.5 \times 10^{3}$ & Thompson \& Munro (1978) \\
\hline Etrumeus micropus & W Sea of Kyushu & $1.9 \times 10^{-3}$ & 3.3 & Chullasorn et al. (1977) \\
\hline Fundulus heteroclitus & Delaware Bay, USA & $1.9 \times 10^{\prime}$ & 2.1 & Meredith \& Lotrich (1979) \\
\hline Gadus macrocephalus & Hecate Strait, British Columbia & $2.5 \times 10^{3}$ & $9.4 \times 10^{2}$ & Ketchen (1964) \\
\hline \multirow{2}{*}{ Gadus minutus } & English Channel & $3.0 \times 10$ & & Menon (1950) \\
\hline & & $2.5 \times 10^{-3}$ & $1.1 \times 10^{1}$ & \\
\hline
\end{tabular}


Appendix (continued)

\begin{tabular}{|c|c|c|c|c|}
\hline Species & Area & $M\left(d^{-1}\right)$ & $W(g)$ & Source \\
\hline \multirow[t]{6}{*}{ Gadus morhua } & Labrador coast & $4.9 \times 10^{-4}$ & $5.5 \times 10^{2}$ & Pinhorn (1975) \\
\hline & Faroe Islands & $4.7 \times 10^{-4}$ & $2.8 \times 10^{3}$ & Jones (1966) \\
\hline & Culf of St. Lawrence & $2.7 \times 10^{-4}$ & $4.2 \times 10^{2}$ & Dickie (1964) \\
\hline & W Baltic Sea & $9.6 \times 10^{-4}$ & $4.1 \times 10^{1}$ & Jensen (1959), Bagge (1974) \\
\hline & S Gulf of St. Lawrence & $5.2 \times 10^{-4}$ & $4.8 \times 10^{2}$ & $\begin{array}{l}\text { Paloheimo \& Kohler (1968), } \\
\text { Kohler et al. (1970) }\end{array}$ \\
\hline & NE Gulf of St. Lawrence & $4.8 \times 10^{-4}$ & $3.9 \times 10^{2}$ & Minet (1978) \\
\hline Galeorhinus australis & SE Australian coast & $\begin{array}{l}2.4 \times 10^{-4} \\
3.0 \times 10^{-4}\end{array}$ & $\begin{array}{l}1.1 \times 10^{5} \\
1.1 \times 10^{5}\end{array}$ & Grant et al. (1979) \\
\hline Glyptocephalus cynoglossus & SW Newfoundland & $5.5 \times 10^{-4}$ & $1.3 \times 10^{2}$ & $\begin{array}{l}\text { Kohler et al. (1970), } \\
\text { Bowering (1977) }\end{array}$ \\
\hline \multirow[t]{2}{*}{ Hippoglossoides platessoides } & Grand Banks & $6.9 \times 10^{-4}$ & $1.4 \times 10^{2}$ & Pitt (1973). \\
\hline & & $6.3 \times 10^{-4}$ & $3.0 \times 10^{2}$ & Kohler et al. (1970) \\
\hline Kátsuwonus pelamis & E Pacific & $4.7 \times 10^{-3}$ & $3.9 \times 10^{2}$ & $\begin{array}{l}\text { Hennemuth (1959) } \\
\text { Joseph \& Calkins (1969) }\end{array}$ \\
\hline Leiognathus splendens & Borneo coast & $4.9 \times 10^{-3}$ & 6.0 & Pauly (1980) \\
\hline Lethrinus enigmatus & S Indian Ocean & $6.3 \times 10^{-4}$ & $1.9 \times 10^{2}$ & Lebeau \& Cueff (1975) \\
\hline Merluccius angustimanus & Gulf of California & $2.2 \times 10^{-3}$ & $3.8 \times 10^{1}$ & Matthews (1975) \\
\hline Merluccius productus & NE Pacific & $1.5 \times 10^{-3}$ & $1.6 \times 10^{2}$ & Nelson \& Larkins (1970) \\
\hline Micropogonias undulatus & N Gulf of Mexico & $8.6 \times 10^{-3}$ & $6.9 \times 10^{2}$ & White \& Chittenden (1977) \\
\hline Mugil cephalus & N Gulf of Mexico & $1.7 \times 10^{-3}$ & $6.5 \times 10^{1}$ & $\begin{array}{l}\text { Broadhead (1953), } \\
\text { Broadhead \& Mefford (1956) }\end{array}$ \\
\hline Neothunnus macropterus & E Pacific & $2.1 \times 10^{-3}$ & $3.0 \times 10^{3}$ & Hennemuth (1961) \\
\hline Nemipterus marginatus & S China Sea & $6.0 \times 10^{-3}$ & $1.3 \times 10^{1}$ & Pauly \& Martosuboro (1980) \\
\hline Notothenia neglecta & S Orkney Islands & $9.9 \times 10^{-4}$ & $2.1 \times 10^{2}$ & Everson $(1970)$ \\
\hline Notothenia rossi & S Georgia, Antarctica & $2.1 \times 10^{-3}$ & $8.9 \times 10^{!}$ & Burchett \& Ricketts (1984) \\
\hline Pagrus pagrus & Caroline coast, USA & $1.5 \times 10^{-3}$ & $3.0 \times 10^{2}$ & Manooch \& Huntsmann (1977) \\
\hline Paralabrax clathrus & California coast & $7.9 \times 10^{-4}$ & $3.3 \times 10^{2}$ & Young (1963) \\
\hline \multirow[t]{4}{*}{ Parophrys vetulus } & Puget Sound, USA & $1.8 \times 10^{-3}$ & $5.0 \times 10^{2}$ & Holland (1969) \\
\hline & & $1.5 \times 10^{-3}$ & $2.2 \times 10^{3}$ & \\
\hline & N Hecate Strait, British Columbi & $1.8 \times 10^{-3}$ & $9.2 \times 10^{2}$ & Ketchen (1947), Holland (1969) \\
\hline & & $9.9 \times 10^{-4}$ & $3.0 \times 10^{3}$ & \\
\hline \multirow[t]{11}{*}{ Pleuronectes platessa } & Wadden Sea & $6.8 \times 10^{-3}$ & 1.2 & Kuipers (1977) \\
\hline & Filey Bay, England & $2.1 \times 10^{-2}$ & $5.0 \times 10^{-1}$ & Kuipers (1977), Lockwood (1980) \\
\hline & & $4.1 \times 10^{-3}$ & $5.0 \times 10 ?$ & \\
\hline & & $1.9 \times 10^{-2}$ & $5.0 \times 10^{-1}$ & \\
\hline & & $1.7 \times 10^{-2}$ & $5.0 \times 10^{-1}$ & \\
\hline & Firemore Bay, Scotland & $4.4 \times 10^{-2}$ & $5.0 \times 10^{-1}$ & \\
\hline & & $3.2 \times 10^{-2}$ & $5.0 \times 10^{-1}$ & \\
\hline & & $2.3 \times 10^{-2}$ & $5.0 \times 10^{-1}$ & \\
\hline & Port Erin Bay, Ireland & $4.6 \times 10^{-2}$ & $5.0 \times 10^{-1}$ & \\
\hline & Red Wharf Bay, N Wales & $1.7 \times 10^{-2}$ & $5.0 \times 10^{-1}$ & Macer (1967), Kuipers (1977) \\
\hline & North Sea & $2.7 \times 10^{-4}$ & $1.2 \times 10^{2}$ & Beverton \& Holt (1957) \\
\hline$P_{\text {seudopeneus maculatus }}$ & S Jamaican Shelf & $5.2 \times 10^{-3}$ & $5.4 \times 10^{1}$ & Munro (1976) \\
\hline \multirow[t]{4}{*}{ Pseudopleuronectes americanus } & Mystic R, Connecticut & $1.2 \times 10^{-2}$ & $3.0 \times 10^{-1}$ & Pearcy (1962b) \\
\hline & & $2.8 \times 10^{-3}$ & 8.4 & \\
\hline & St. Mary's Bay, Nova Scotia & $9.9 \times 10^{-4}$ & $2.0 \times 10^{2}$ & Dickie \& McCracken (1955) \\
\hline & Massachusetts coast & $7.5 \times 10^{-4}$ & $1.8 \times 10^{2}$ & $\begin{array}{l}\text { Lux (1969). } \\
\text { Howe \& Coates (1975) }\end{array}$ \\
\hline Pseudosciaena diacanthus & E Indian Ocean & $2.3 \times 10^{-3}$ & $1.2 \times 10^{3}$ & Rao $(1966,1968)$ \\
\hline Pseudosciaena manchurica & E China and Yellow Seas & $2.7 \times 10^{-3}$ & $1.6 \times 10^{1}$ & Mako (1961) \\
\hline Rastrelliger kanagurta & Java Sea & $1.2 \times 10^{-2}$ & $1.8 \times 10^{1}$ & Sudjastani (1974) \\
\hline Rastrelliger neglectus & Gulf of Thailand & $1.7 \times 10^{-3}$ & $1.9 \times 10^{1}$ & Hongskul (1974) \\
\hline Rhombosolea plebeja & Canterbury, New Zealand & $3.4 \times 10^{-3}$ & $9.1 \times 10^{1}$ & Webb (1972), Colman (1978) \\
\hline Sardinops ocellatus & Walvis Bay, S Africa & $1.6 \times 10^{-3}$ & $3.5 \times 10^{1}$ & Newman $(1970)$ \\
\hline & E China and Yellow Seas & $1.2 \times 10^{-3}$ & $1.3 \times 10^{2}$ & Mako (1961) \\
\hline \multirow[t]{2}{*}{ Scomber scombrus } & New England coast & $9.6 \times 10^{-4}$ & $9.7 \times 10^{1}$ & Paciorkowski et al. (1973) \\
\hline & & $9.0 \times 10^{-4}$ & $1.1 \times 10^{2}$ & Isakov $(1974)$ \\
\hline \multirow[t]{4}{*}{ Sebastes alutus } & NE Pacific & $6.4 \times 10^{-4}$ & $2.0 \times 10^{2}$ & $\begin{array}{l}\text { Westrheim \& Snytko (1974), } \\
\text { Gunderson (1977) }\end{array}$ \\
\hline & Queen Charlotte Sound & $1.8 \times 10^{-4}$ & $2.1 \times 10^{2}$ & \\
\hline & Gult of Alaska & $5.3 \times 10^{-4}$ & $9.4 \times 10^{1}$ & $\begin{array}{l}\text { Westrheim \& Snytko (1974), } \\
\text { Chikuni (1975) }\end{array}$ \\
\hline & Aleutian Islands & $1.2 \times 10^{-3}$ & $1.2 \times 10^{2}$ & \\
\hline Sphyraena argentea & California coast & $5.0 \times 10^{-4}$ & $4.7 \times 10^{2}$ & Pinkas (1966) \\
\hline
\end{tabular}


Appendix (continued)

\begin{tabular}{|c|c|c|c|c|}
\hline Species & Area & $M\left(d^{-1}\right)$ & $W(g)$ & Source \\
\hline Sprattus sprattus & Skagerak, Sweden & $2.9 \times 10^{-3}$ & 6.4 & $\begin{array}{l}\text { Johnson (1970), } \\
\text { Lindquist (1978) }\end{array}$ \\
\hline & North Sea & $3.3 \times 10^{-3}$ & 4.3 & Bailey $(1980)$ \\
\hline Stenotomus chrysops & E Long Is. Sound & $4.4 \times 10^{-3}$ & $5.7 \times 10^{!}$ & $\begin{array}{l}\text { Briggs (1968), } \\
\text { Finkelstein (1971) }\end{array}$ \\
\hline Taius tumifrons & E China Sea & $5.5 \times 10^{-4}$ & $1.4 \times 10^{2}$ & Shindo $(1960)$ \\
\hline Thunnus obesus & Central Atlantic & $1.2 \times 10^{-3}$ & $1.5 \times 10^{4}$ & Lenarz (1974), Kume (1977) \\
\hline & Pacific Ocean & $9.9 \times 10^{-4}$ & $5.7 \times 10^{3}$ & $\begin{array}{l}\text { Silliman (1966) } \\
\text { Suda \& Kume (1967) }\end{array}$ \\
\hline Trachurus japonicus & E China Sea & $2.7 \times 10^{-3}$ & $2.8 \times 10^{1}$ & Mitani \& Shojima (1966) \\
\hline Trichiurus lepturus & E China and Yellow Seas & $9.9 \times 10^{-4}$ & $6.1 \times 10^{1}$ & Misu (1964) \\
\hline Trisopterus esmarkii & N North Sea & $4.4 \times 10^{-3}$ & 3.4 & Raitt (1968) \\
\hline Urolophus paucimaculatus & Victoria State, Australia & $1.2 \times 10^{-3}$ & $7.8 \times 10^{1}$ & Edwards (1980) \\
\hline Urophysis chuss & Georges Bank & $2.3 \times 10^{-3}$ & $5.1 \times 10^{1}$ & $\begin{array}{l}\text { Kohler et al. (1970), } \\
\text { Rikhter (1974) }\end{array}$ \\
\hline \multicolumn{5}{|l|}{ Whales } \\
\hline Balaenopterus borealis & S Africa coast & $1.6 \times 10^{-4}$ & $3.6 \times 10^{6}$ & Lockyer $(1977 a, b)$ \\
\hline Eschrichtius robustus & E Pacific Ocean & $\begin{array}{l}2.2 \times 10^{-4} \\
2.6 \times 10^{-4}\end{array}$ & $\begin{array}{l}5.0 \times 10^{6} \\
5.8 \times 10^{6}\end{array}$ & Rice \& Wolman (1971) \\
\hline Megaptera novaeangliae & Antarctic Ocean & $\begin{array}{l}2.4 \times 10^{-4} \\
2.4 \times 10^{-4}\end{array}$ & $\begin{array}{l}5.8 \times 10^{6} \\
6.6 \times 10^{6}\end{array}$ & $\begin{array}{l}\text { Chittleborough (1965), } \\
\text { Lockyer (1976) }\end{array}$ \\
\hline Physeter catodon & S Africa coast & $\begin{array}{l}1.6 \times 10^{-4} \\
1.6 \times 10^{-4}\end{array}$ & $\begin{array}{l}6.6 \times 10^{6} \\
3.1 \times 10^{6}\end{array}$ & $\begin{array}{l}\text { Gambell (1974), } \\
\text { Allen \& Kirkwood (1977) }\end{array}$ \\
\hline
\end{tabular}

\section{LITERATURE CITED}

Aasen, O. (1952). The Lusterfjord herring. Fisk. Dir. Skr., Ser. Havunders. $10(2)$

Ahlstrom, E. H. (1966). Distribution and abundance of sardine and anchovy larvae in the California Current region off California and Baja California, 1951-64, a surnmary. Spec. Scient. Rep. U.S. Fish Wildl. Serv. (Fisheries) No. 534

Allen, K. R., Kirkwood, G. P. (1977). Further development of sperm whale population models. Int. Whaling Comm. Rep. 27: $106-112$

Amaratunga, T., Roberge, M., Wood, L. (1978). An outline of the fishery and biology of the short-finned squid, Illex illecebrosus, in Eastern Canada. In: Balch, N., Amaratunga, T, O'Dor, R. K. (ed.) Proceedings of the workshop on Illex illecebrosus. Tech. Rep. Fish. Mar. Serv. Canada No. 833 , p. $2.1-2.17$

Anderson, J. T. (1984). Early life history of redfish (Sebastes spp.) on Flemish Cap. Can. J. Fish. Aquat. Sci. 41: 1106-1116

Bagenal, T. B. (1971). The interrelation of the size of fish eggs, the date of spawning and the production cycle. J. Fish Biol. 3: 207-219

Bagge, O. (1974). The Danish cod fishery in the Baltic 1957-70. Rapp. P.-v. Réun. Cons. int. Explor. Mer 166: $103-105$

Bailey, R. S. (1974). The life history and biology of the blue whiting in the northeast Atlantic. I. The planktonic phase in the Rockall area. Mar. Ser. Scotl. 1974 (1): 1-29

Bailey, R. S. (1980). Problems in the management of shortlived pelagic fish as exemplified by North Sea sprat. Rapp. P.-v. Réun. Cons. int. Explor. Mer 177: 477-488

Bannister, R. C. A., Harding, D., Lockwood, S. J. (1974). Larval mortality and subsequent year class strength in the plaice (Pleuronectes platessa L.). In: Blaxter, J. H. S. (ed.) The early life history of fish. Springer-Verlag, Berlin, p. 21-37

Banse, K., Mosher, S. (1980). Adult body mass and annual production/biomass relationships of field populations Ecol. Monogr. 50: 355-379

Bayliff, W. H. (1966). Population dynamics of the anchoveta Cetengraulis mysticetus, in the Gulf of Panama, as determined by tagging experiments. Bull. Inter-Am. Trop. Tuna Comm. 11: $1-288$

Berkes, F. (1977). Production of the euphausid crustacean Thysanoessa raschi in the Gulf of St. Lawrence. J. Fish. Res. Bd Can. 34: 443-446

Berrien, P. L., Naplin, N. A., Pennington, M. R. (1981). Atlantic mackerel, Scomber scombrus, egg production and spawning population estimates for 1977 in the Gulf of Mexico, Georges Bank, and middle Atlantic Bight. Rapp. P.-v. Réun. Cons. int. Explor. Mer 178: 279-288

Beverton, R. J. H., Holt, S. J. (1956). A review of methods for estimating mortality rates in exploited populations, with special reference to causes of bias in catch sampling. Rapp. P.-v. Réun. Cons. int. Explor. Mer 140: 67-83

Beverton, R. J. H., Holt, S. J. (1957). On the dynamics of exploited fish populations. U.K. Min. Agric. Fish., Fish. Invest., London, Series II, 19, p. 1-533

Bowering, W. R. (1977). The status of the witch flounder fishery in ICNAF Subdivision 3PS. ICNAF Select. Pap. No. 2: $11-14$

Briggs, P. T (1968). The sport fisheries in the inshore waters of eastern Long Island. N.Y. Fish Game J. 15: 165-185

Brinton, E. (1976). Population biology of Euphausia pacifica off southern California. Fish. Bull. U.S. 74: 733-762

Broadhead, G. C. (1953). Investigations of the black mullet, Mugil cephalus L., in northwest Florida. Florida State Board of Conservation, Tech. Ser. No. 7, p. 1-34

Broadhead, G. C., Mefford, H. P. (1956). The migration and exploitation of the black mullet, Mugil cephalus L., in Florida, as determined from tagging during 1949-1953. Florida State Board of Conservation, Tech. Ser. No. 18, p. $1-31$

Burchett, M. S., Ricketts, C. (1984). The population dynamics 
of Notothenia rossi from South Georgia (Antarctica). Polar Biology 3: 35-38

Burd, A. C., Bracken, J. (1965). Studies on the Dunmore herring stock. I. A population assessment. J. Cons. int. Explor. Mer 29: 277-301

Chavance, P., Flores-Coto, C., Sanchez-Iturbe, A. (1984). Early life history and adult biomass of sea bream in the Terminos Lagoon, southern Gulf of Mexico. Trans. Am. Fish. Soc. 113: 166-177

Chikuni, S. (1975). Biological studies on the population of the Pacific ocean perch in the North Pacific. Bull. Far Seas Fish. Res. Lab. No. 12: 1-119

Chittleborough, R. G. (1965). Dynamics of two populations of the humpback whale, Megaptera novaeangliae (Borowski). Aust. J. mar. Freshwat. Res. 16: 33-128

Chullasorn, S., Mako, H., Oka, M., Matsushita, Y. (1977). Studies on the fishery biology of the round herring in the western Sea of Kyushu. Seikai Reg. Fish. Res. Lab. 50 $37-71$

Ciechomski, J. Dz. de, Capezzani, D. A. (1973). Studies on the evaluation of the spawning stocks of the Argentinean anchovy, Engraulis anchoita, on the basis of egg surveys. Rapp. P.-v. Réun. Cons. int. Explor. Mer 164: 293-301

Colman, J. A. (1978). Tagging experiments on the sand flounder, Rhombosolea plebeia (Richardson), in Canterbury, New Zealand, 1964 to 1966. Fish. Res. Dir. N.Z. Ministry Agric. Fish., Fish. Res. Bull. No. 18

Conand, F. (1977). Oeufs et larves de la sardinelle ronde (Sardinella aurita) au Sénégal; distribution, croissance, mortalité, variations d'abondance de 1971 a 1976. Cah. ORSTOM (Ser Oceanogr.) 15: 201-214

Conand, F., Fagetti, E. (1971). Description et distribution saisonnière des larves de sardinelles des côtes du Sénégal et de la Gambie en 1968 et 1969. Cah. ORSTOM (Ser. Oceanogr.) 9: 293-318

Crossland, J. (1980). The number of snapper, Chrysophrys auratus (Forster), in the Hauraki Gulf, New Zealand, based on egg surveys in 1974-75 and 1975-76. N.Z. Fish. Res. Bull. No. 22

Cushing, D. H., Bridger, J. P. (1966). The stock of herring in the North Sea, and changes due to fishing. Fish. Invest., London, Series II, 25: 1-123

Dahlberg, M. D. (1979). A review of survival rates of fish eggs and larvae in relation to impact assessments. Mar. Fish. Rev. U.S. 41: 1-12

Das, N. (1968). Spawning, distribution, survival and growth of larval herring (Clupea harengus L.) in relation to hydrographic conditions in the Bay of Fundy. Fish. Res. Bd Can. Tech. Rep. No. 88: 1-129

Dickie, L. M. (1964). Estimation of mortality rates of Gulf of St. Lawrence cod from results of a tagging experiment. ICNAF Special Publ. No. 4: 71-80

Dickie, L. M., McCracken, E. D. (1955). Isopleth diagrams to predict equilibrium yields of a small flounder fishery. J. Fish. Res. Bd Can. 12: 187-209

Dragesund, O. (1970). Distribution, abundance and mortality of young and adolescent Norwegian spring spawning herring (Clupea harengus Linné) in relation to subsequent year-class strength. Fisk. Dir. Skr., Ser Havunders. 15: 451-556

Dragesund, O., Nakken, O. (1971a). Relationship of parent stock size and year class strength in Norwegian spring spawning herring. Rapp. P.-v. Réun. Cons. int. Explor. Mer 164: 15-29

Dragesund, O., Nakken, O. (1971b). Mortality of herring during the early larval stage in 1967. Rapp. P.-v. Réun. Cons. int. Explor. Mer 164: 142-146
Durbin, A. G., Durbin, E. G. (1981). Standing stock and estimated production rates of phytoplankton and zooplankton in Narragansett Bay, Rhode Island. Estuaries 4: $24-41$

Edwards, R. R. C. (1980). Aspects of the population dynamics and ecology of the white spotted stingaree, Urolophus paucimaculatus Dixon, in Port Phillip Bay, Victoria. Aust. J. mar. Freshwat. Res. 31: 459-467

Everson, I. (1970). The population dynamics and energy budget of Notothenia neglecta Nybelin at Signy Island, South Orkney Islands. Bull. Brit. Antarct. Surv. 23: 25-50

Farris, D. A. (1961). Abundance and distribution of eggs and larvae and survival of larvae of jack mackerel (Trachurus symmetricus). Fish. Bull. U.S. 61: 247-279

Finkelstein, S. L. (1971). Migration, rate of exploitation and mortality of scup from the inshore waters of eastern Long Island Sound. N.Y. Fish Game J. 18: 97-111

Gambell, R. (1974). Sperm whales off Durban. In: Schevill, W. E. (ed.) The whale problem: a status report. Harvard University Press, Cambridge, p. 87-96

Grant, C. J., Sandland, R. L., Olsen, A. M. (1979). Estimation of growth, mortality and yield per recruit of the Australian school shark, Galeorhinus australis (MacLeay), from tag recoveries. Aust. J. mar. Freshwat. Res. 30: 625-638

Gunderson, D. R. (1977). Population biology of Pacific Ocean perch, Sebastes alutus, stocks in the Washington-Queen Charlotte Sound region, and their response to fishing. Fish. Bull. U.S. 75: 369-403

Harding, D., Talbot, J. W. (1973). Recent studies on the eggs and larvae of the plaice (Pleuronectes platessa L.) in the southern Bight. Rapp. P.-v. Réun. Cons. int. Explor. Mer 164: 261-269

Harding, D., Nichols, J. H., Tungate, D. S. (1978). The spawning of the plaice (Pleuronectes platessa L.) in the southern Bight. Rapp. P.-v. Réun. Cons. int. Explor. Mer 172: 102-113

Heinle, P. R. (1966). Production of a calanoid copepod, Acartia tonsa, in the Patuxent River estuary. Chesapeake Sci. 7 : $59-74$

Heinle, P. R., Flemer, D. A. (1975). Carbon requirements of a population of the estuarine copepod, Eurytemora affinus. Mar. Biol. 31: 235-247

Henderson, P. A., Whitehorse, J. W., Cartwright, G. H. (1984). The growth and mortality of larval herring, Clupea harengus harengus L., in the River Blackwater estuary, 1978-1980. J. Fish Biol. 24: 613-622

Hennemuth, R. C. (1959). Additional information on the length-weight relationship of skipjack tuna from the eastern tropical Pacific Ocean. Bull. Inter-Am. Trop. Tuna Comm. 4: 25-37

Hennemuth, R. C. (1961). Year-class abundance, mortality and yield-per-recruit of yellowfin tuna in the eastern Pacific ocean, 1954-1959. Bull. Inter-Am. Trop. Tuna Comm. 6: $1-51$

Hewitt, R. D. (1981). The value of pattern in the distribution of young fish. Rapp. P.-v. Réun. Cons. int. Explor. Mer 178: 229-236

Hewitt, R. D., Methot, R. D. (1982). Distributions and mortality of northern anchovy larvae in 1978 and 1979. California Coop. Fish. Invest. Rep. 23: 226-245

Hewitt, R. D., Theilacker, G. H., Lo, N. C. H. (1985). Causes of mortality in young jack mackerel. Mar. Ecol. Prog. Ser. 26 . $1-10$

Hirota, J. (1974). Quantitative natural history of Pleurobranchia bachei in La Jolla Bight. Fish. Bull. U.S. 72: 295-335

Hiyashi, S. (1966). A note on the biology and fishery of the 
Japanese anchovy Engraulis japonica. California Coop. Fish. Invest. Rep. 11:44-57

Holland, G. A. (1969). Age, growth, and mortality of races of English sole (Parophrys vetulus) in Puget Sound, Washington. Pacif. Mar. Fish. Comm. Bull. 7: 35-50

Hongskul, V. (1974). Population dynamics of Platu, Rastrelliger neglectus (van Kampen), in the Gulf of Thailand. Proc. Indo-Pacif. Fish. Council 15: 297-350

Houde, E. D. (1977a). Abundance and potential yield of the round herring, Etrumeus teres, and aspects of its early life history in the eastern Gulf of Mexico. Fish. Bull. U.S. 75 : $61-90$

Houde, E. D. (1977b). Abundance and potential yield of the Atlantic thread herring, Opisthonema oglinum, and aspects of its early life history in the eastern Gulf of Mexico. Fish. Bull. U.S. 75: 493-512

Houde, E. D. (1977c). Abundance and potential yield of the scaled sardine, Harengula jaguana, and aspects of its early life history in the eastern Gulf of Mexico. Fish. Bull. U.S. 75: 613-628

Houde, E. D., Lovdal, J. D. A. (1985). Patterns of variability in ichthyoplankton occurrence and abundance in Biscayne Bay, Florida. Estuar. coast. Shelf Sci. 20: 79-103

Howe, A. B., Coates, P. G. (1975). Winter flounder movements, growth, and mortality off Massachusetts. Trans. Am. Fish. Soc. 104: 13-29

Hughes, S. E. (1974). Stock composition, growth, mortality, and availability of Pacific saury, Colabis saira, of the northeastern Pacific Ocean. Fish. Bull. U.S. 72: 121-131

Hurley, G. V., Mohn, R. K. (1978). Considerations on the management of the international squid (lllex) fishery in ICNAF Subarea 4. In: Balch, N., Amaratunga, T., O Dor, R. $\mathrm{K}$. (ed.) Proceedings of the workshop on lllex illecebrosus. Tech. Rep. Fish. Mar. Serv. Canada No. 833, p. 7.1-7.14

lizuka, A. (1966). Studies on the early life history of herring (Clupea pallasi C. et V.) in Akkeshi Bay and Lake Akkeshi. Hokkaido. Rull Hokkaido Reg. Fish. Res. Lab. 31: $18-63$

lles, T D., Sinclair, M. (1982). Atlantic herring stock discreteness and abundance. Science (Wash., D.C.) 215: 627-633

Isakov, V I. (1974). The estimation of natural mortality and optimum fishing intensity of mackerel from the New England area. Int. Comm. Northw. Atlant. Fish., Res. Doc., 74/ 108, Ser. No. 3346 (mimeo)

Iverson, E. S., Moffett, A. W. (1962). Estimation of abundance and mortality of a spotted seatrout population. Trans. Am. Fish. Soc. 91: 395-398

Jensen, A. J. C. (1959). Danish investigations on the stocks of cod, plaice, flounder, and dab in the central Baltic and the fishery for these species in the western Baltic. Rapp. P.-v. Réun. Cons. int. Explor. Mer 147: 14-23

Johnson, P. O. (1970). The Wash sprat fishery. Fish. Invest., London, Series II, 26: 1-88

Jones, B. W. (1966). The cod and the cod fishery at Faroe. Fish. Invest., London, Series II, 24: 1-32

Jones, R. (1973). Density-dependent regulation of the numbers of cod and haddock. Rapp. P.-v. Réun. Cons. int. Explor. Mer 164: 119-127

Joseph, J., Calkins, T. P. (1969). Population dynamics of the skipjack tuna (Katsuwonas pelamis) of the eastern Pacific ocean. Bull. Inter-Am. Trop. Tuna Comm. 13: 7-119

Kendall, A. W., Jr., Gordon, D. (1981). Growth rate of Atlantic mackerel (Scomber scombrus) larvae in the middle Atlantic Bight. Rapp. P.-v. Réun. Cons. int. Explor. Mer 178: $337-341$

Ketchen, K. S. (1947). The age, growth and mortality of the lemon sole (Parophrys vetulus Girard) on the British Co- lumbia fishing grounds. M. A. thesis, University of British Columbia, Vancouver

Ketchen, K. S. (1964). Preliminary results of studies on growth and mortality of Pacific cod (Gadus macrocephalus) in Hecate Strait, British Columbia. J. Fish. Res. Bd Can. 21: 1051-1067

Ketchen, K. S., Forrester, C. R. (1966). Population dynamics of the petrale sole, Eopsetta jordani, in waters off western Canada. Bull. Fish. Res. Bd Can. No. 153

Kohler, A. C., Fitzgerald, D. N. Halliday, R. G., Scott, J. S., Tyler, A. V (1970). Length-weight relationships of marine fishes of the Canadian Atlantic region. Fish. Res. Bd Can. Tech. Rep. No. 164

Koslow, J. A., Brault, S., Dugas, J., Page, F. (1985). Anatomy of an apparent year-class failure: the early life history of the 1983 Browns Bank haddock Melanogrammus aeglefinus. Trans. Am. Fish. Soc. 114: 478-489

Kuipers, B. P. (1977). On the ecology of juvenile plaice on a tidal flat in the Wadden Sea. Neth. J. Sea Res. 11: 56-91

Kume, S. (1977). Recent status of bigeye tuna in the Atlantic Ocean. Int Comm. Conserv. Atlant. Tuna Coll. Vol. Sci. Pap., Vol. VI: 162-167

Lambert, T. C., Ware, D. M. (1984). Reproductive strategies of demersal and pelagic spawning fish. Can. J. Fish. Aquat. Sci. 41: $1565-1569$

Lasker, R. (1985). What limits clupeoid production? Can. J. Fish. Aquat. Sci. 42 (Suppl. 1): 31-38

Laurence, G. C. (1979). Larval length-weight relations for seven species of northwest Atlantic fishes reared in the laboratory. Fish. Bull. U.S. 76: 890-895

Lebeau, A., Cueff, J. C. (1975). Biologie et peche du Capitaine, Lethrinus enigmatus (Smith 1959), du Banc de Malha (Ocean Indien). Rev. Trav. Inst. Pêches Marit. 39: 415-442

Lenarz, W. H. (1973). Dependence of catch rates on size of fish larvae. Rapp. P.-v. Réun. Cons. int. Explor. Mer 164: $270-275$

Lenarz, W. H. (1974). Length-weight relations for five eastern tropical Atlantic scombrids. Fish. Bull. U.S. 72: 848-851

Lindley, J. A. (1978). Population dynamics and production of euphausiids. I. Thysanoessa longicaudata in the North Atlantic Ocean. Mar. Biol. 46: 121-130

Lindley, J. A. (1980). Population dynamics and production of euphausiids. II. Thysanoessa inermis and T. raschi in the North Sea and American coastal waters. Mar. Biol. 59: 225-233

Lindley, J. A., Williams, R. (1980). Plankton of the Fladen Ground during FLEX 76. II. Population dynamics and production of Thysanoessa inermis (Crustacea: Euphausacea). Mar Biol. 57:79-86

Lindquist, A. (1978). A century of observations on sprat in the Skagerrak and the Kattegat. Rapp. R.-v. Réun. Cons. int. Explor. Mer 172: 187-196

Lloyd, M. (1967). 'Mean crowding'. J. Anim. Ecol. 36: 1-30

Lockwood, S. J. (1980). Density-dependent mortality in Ogroup plaice (Pleuronectes platessa L.) populations. J. Cons. int. Explor. Mer 39: 148-153

Lockyer, C. (1976). Body weights of some species of large whales. J. Cons. int. Explor. Mer 36: 259-273

Lockyer, C. (1977a). Mortality estimates for mature southern sei whales. Rep. Int. Whaling Comm., Spec. Issue No. 1: $53-57$

Lockyer, C. (1977b). Some estimates of growth in the sei whale, Balaenoptera borealis. Rep. Int. Whaling Comm., Spec. Issue No. 1: 58-62

Lough, R. G., Bolz, G. R., Grosslein, M. D., Potter, D. C. (1981). 
Abundance and survial of sea herring (Clupea harengus L.) larvae in relation to environmental factors, spawning stock size, and recruitment for the Georges Bank area, 1968-1977. Rapp. P.-v. Réun. Cons. int. Explor. Mer 178: $220-222$

Lux, F. E. (1969). Length-weight relationships of six New England flatfishes. Trans. Am. Fish. Soc. 98: 617-621

Macer, C. T. (1967). The food web in Red Wharf Bay (North Wales) with particular reference to young plaice (Pleuronectes platessa). Helgoländer wiss. Meeresunters. 15: $560-573$

Mako, H. (1961). Studies on the demersal fish resources in the East China and Yellow Seas, based on the fishery statistics by the market categories in fish size. Bull. Seikai Reg. Fish. Res. Lab. 24: 1-113

Manooch, C. S. III, Huntsman, G. R. (1977). Age, growth, and mortality of the red porgy, Pagrus pagrus. Trans. Am. Fish. Soc. 106: 26-33

Matthews, C. P. (1975). Some observations on the ecology and the population dynamics of Merluccius angustimanus in the south Gulf of California. J. Fish Biol. 7: 83-94

May, R. C. (1974). Larval mortality in marine fishes and the critical period concept. In: Blaxter, J. H. S. (ed.) The early life history of fish. Springer-Verlag, New York, p. 3-20

McGurk, M. D. (1984). Effects of delayed feeding and temperature on the age of irreversible starvation and on the rates of growth and mortality of Pacific herring larvae. Mar. Biol. 84: 13-26

McGurk, M. D. (1986). The role of starvation in the population of larval Pacific herring, Clupea harengus pallasi. Ph.D. thesis, University of British Columbia, Vancouver

Menon, M. D. (1950). Bionomics of the poor-cod (Gadus minutus L.) in the Plymouth area. J. mar. biol. Ass. U.K. 29: $185-239$

Meredith, W. H., Lotrich, V. A. (1976). Production dynamics of a tidal creek population of Fundulus heteroclitus (Linnaeus). Estuar. coast. mar. Sci. 8: 99-118

Minet, J. P. (1978). Dynamics and yield assessment of the northeastern Gulf of St. Lawrence cod stock. Sel. Pap. ICNAF 3: 1-16

Misu, H. (1964). Fisheries biology of the ribbon fish (Trichurus leptus Linné) in the East China and the Yellow Seas. Bull. Seikai Reg. Fish. Res. Lab. 32: 1-58

Mitani, F., Shojima, E. (1966). Studies on the resources of jack mackerel, Trachurus japonicus (Temminck et Schlegel), in the East China Sea. III. Natural and fishing mortality coefficients. Bull. Jap. Soc. Sci. Fish. 32: 57-63

Munro, J. L. (1976). Aspects of the biology and ecology of Caribbean reef fishes: Mullidae (goat-fishes). J. Fish Biol. 9: 79-97

Nakai, Z., Hattori, S. (1962). Quantitative distribution of eggs and larvae of the Japanese sardine by year 1949 through 1951. Bull. Tokai Reg. Fish. Res. Lab. 9: 23-60

Nelson, M. O., Larkins, H. A. (1970). Distribution and biology of Pacific hake: a synopsis. U.S. Fish Wildl. Serv. Circ. 332: $23-33$

Newbury, T. K., Bartholemew, E. F. (1976). Secondary production of microcopepods in the southern eutropic basin of Kaneohe Bay, Oahu, Hawailan Islands. Pacif. Sci. 30: 373-384

Newman, G. G. (1970). Stock assessment of the pilchard, Sardinops ocellata, at Walvis Bay, southwest Africa. Invest. Rep. Div. Sea Fish. S. Afr. 85: 1-13

O'Connell, C. P. (1980). Percentage of starving northern anchovy, Engraulis mordax, in the sea as estimated by histological methods. Fish. Bull. U.S. 78: 475-489

Paciokowski, A., Liwoch, M., Grzebielec, R., Borokowski, W.,
Ucinski, S. (1973). A preliminary assessment of mackerel stock of ICNAF Subarea 5 and Statistical Area 6, 1968-1972. Int. Comm. Northw. Atlant. Fish., Res. Doc., 73/98, Ser. No. 3058 (mimeo)

Paloheimo, J. E., Kohler, E. C. (1968). Analysis of the southern Gulf of St. Lawrence cod population. J. Fish. Res. Bd Can. 25: $555-578$

Paulik, G. J. (1963). Estimates of mortality rates from tag recoveries. Biometrics 19: 28-57

Pauly, D. (1980). The use of a pseudo catch-curve for the estimation of mortality rates in Leiognathus splendens (Pisces: Leiognathidae) in Indonesian waters. Meeresforschung Rep. Mar. Res. 28: 56-60

Pauly, D., Martosuboro, P. (1980). The population dynamics of Nemipterus marginatus (Cuvier and Val) off western Kalimantan, South China Sea. J. Fish Biol. 17. 263-274

Pearcy, W G. (1962a). Ecology of an estuarine population of winter flounder, Pseudopleuronectes americanus (Walbaum). II. Distribution and dynamics of larvae. Bull. Bingham Oceanogr. Coll. 18: 16-37

Pearcy, W. G. (1962b). Ecology of an estuarine population of winter flounder, Pseudopleuronectes americanus (Walbaum). III. Distribution, abundance, growth, and production of juveniles, survival of larvae and juveniles. Bull. Bingham Oceanogr. Coll. 18: 39-64

Peterson, I., Wroblewski, J. S. (1984). Mortality rate of fishes in the pelagic ecosystem. Can. J. Fish. Aquat. Sci. 41: $1117-1120$

Pielou, E. C. (1977). Mathematical ecology. John Wiley and Sons, New York

Pinhorn, A. T. (1975). Estimates of natural mortality for the cod stock complex in ICNAF Divisions $2 \mathrm{~J}, 3 \mathrm{~K}$, and $3 \mathrm{~L}$. ICNAF Res. Bull. No. 11: 31-36

Pinkas, L. (1966). A management study of the California barracuda, Sphyraena argentea Girard. Calif. Dept. Fish Game, Fish. Bull. No. 134

Pitt, T K. (1973). Assessment of American plaice stocks on the Grand Bank, ICNAF Divisions 3L and 3N. ICNAF Res. Bull. 10: 63-77

Qasim, S. Z. (1957). The biology of Blennius pholis L. (Teleostei). Proc. zool. Soc. Lond. 128: 161-208

Raitt, D. F. S. (1968). The population dynamics of the Norway pout in the North Sea. Mar. Ser Scot. 1968 (5)

Reay, P. J. (1973). Some aspects of the biology of the sandeel, Ammodytes tobianus L., in Langstone Harbour, Hampshire. J. mar biol. Ass. U.K. 53: 325-346

Rao, V. S. (1966). Age and growth of 'Ghol', Pseudosciaena diacanthus (Lacépède), in Bombay and Saurashtra waters. Indian J. Fish. 13: 251-291

Rao, V S. (1968). Estimates of mortality and yield per recruitment of 'Ghol', Pseudosciaena diacanthus (Lacépède). Indian J. Fish. 15: 88-98

Rice, D. W., Wolman, A. A. (1971). The life history and ecology of the grey whale (Eschrichtius robustus). Am. Soc. Mammal., Spec. Publ. No. 3

Ricker, W. E. (1973). Linear regressions in fishery research. J Fish. Res. Bd Can. 30: 409-434

Ricker, W. E. (1975). Computation and interpretation of the biological statistics of fish populations. Bull. Fish. Res. Bd Can. No. 191

Rikhter, V. A. (1974). A study of the dynamics of red hake (Urophysis chuss) catches from the Northwest Atlantic by the method of simulation. J. Ichthyology 14: 484-491

Riley. J. D. (1974). The distribution and mortality of sole eggs [Solea solea (L.)] in inshore areas. In: Blaxter, J. H. S. (ed.) The early life history of fish. Springer-Verlag, Berlin, p. $39-52$ 
Russell, F. S. (1976). The eggs and planktonic stages of British marine fishes. Academic Press, New York

Ryland, J. S. (1966). Observations on the development of larvae of the plaice, Pleuronectes platessa L., in aquaria. $\mathrm{J}$ Cons. int. Explor. Mer 30: 177-195

Saville, A. (1956). Eggs and larvae of haddock (Gadus morhua L.) at Faroe. Mar. Ser Scot. 1954 (4)

Schaaf, W. E., Huntsman, G. R. (1972). Effect of fishing on the Atlantic menhaden stock: 1955-1969. Trans. Am. Fish. Soc. 101: 290-297

Schmidt-Nielsen, K. (1984). Scaling: why is animal size so important? Cambridge University Press, New York

Sette, O. E. (1943). Biology of the Atlantic mackerel (Scomber scombrus) of North America. Part 1: Early life history, including the growth, drift, and mortality of the egg and larval populations. Fish. Bull. U.S. 50: 149-237

Shelbourne, J. E. (1957). The feeding and condition of plaice larvae in good and bad plankton patches. J. mar. biol. Ass. U.K. 36: 539-552

Shindo, S. (1960). Studies on the yellow sea bream in the East China Sea. Bull. Seikai Reg. Fish. Res. Lab. No. 20

Silliman, R. P. (1966). Estimates of yield for Pacific skipjack and bigeye tuna. In: Manar, T. E. (ed.) Proceedings of the Governor's conference on central Pacific fish resources. State of Hawaii, U.S.A., p. 231-249

Smith, P. E. (1973). The mortality and dispersal of sardine eggs and larvae. Rapp. P.-v. Réun. Cons. int. Explor. Mer 164: 282-292

Stepien, W. P., Jr. (1976). Feeding of laboratory-reared larvae of the sea bream Archosargus rhomboidalis (Sparidae). Mar. Biol. 38: 1-16

Stevenson, J. C. (1962). Distribution and survival of herring larvae (Clupea pallasi Valciennes) in British Columbia waters. J. Fish. Res. Bd Can. 19: 735-810

Suda, A., Kume, S. (1967). Survival and recruitment of bigeye tuna in the Pacific Ocean, estimated by the data of tuna longline catch. Rep. Nankei Reg. Fich Res I.ab 25: 91-103

Sudjastani, T. (1974). The species of Rastrelliger in the Java Sea, their taxonomy, morphometry and population dynamics. M.Sc. thesis, University of British Columbia, Vancouver

Talbot, J. W. (1977). The dispersal of plaice eggs and larvae in the Southern Bight of the North Sea. J. Cons. int. Explor. Mer 37: 221-248

Theilacker, G. T., Dorsey, K. (1980). Larval fish diversity, a summary of laboratory and field research. In: Workshop on the effect of environmental variation on the survival of larval pelagic fishes, Washington, D.C., FAO, Intergovernmental Oceanographic Commission Workshop Report No. 28, p. 105-142

Thomas, J. C. (1968). Management of the white seabass
(Cynoscion nobilis) in California waters. Calif. Dept. Fish Game Bull. No. 142

Thompson, R., Munro, J. L. (1978). Aspects of the biology and ecology of Caribbean reef fishes: Serranidae (hinds and groupers). J. Fish. Biol. 12: 115-146

Ursin, E. (1967). A mathematical model of some aspects of fish growth, respiration, and mortality. J. Fish. Res. Bd Can. 24: $2355-2453$

Vooren, C. M. (1977). Growth and mortality of tarakihi (Pisces: Cheilodactylidae) in lightly fished populations. N.Z. Jl mar. Freshwat. Res. 11: 1-22

Ware, D. M. (1975). Relation between egg size, growth, and natural mortality of larval fish. J. Fish. Res. Bd Can. 32: 2503-2512

Ware, D. M., Lambert, T. C. (1985). Early life history of Atlantic mackerel (Scomber scombrus) in the southern Gulf of St. Lawrence. Can. J. Fish. Aquat. Sci. 42: 577-592

Watanabe, T. (1970). Morphology and ecology of early stages of life in Japanese common mackerel, Scomber japonicus Houttuyn, with special reference to fluctuations of populations. Bull. Tokai Reg. Fish. Res. Lab. 62: 1--283

Webb, B. F. (1972). Fish populations of the Avon-Heathcote estuary. I. General ecology, distribution, and length-frequency. N.Z. Jl mar. Freshwat. Res. 6: 570-601

Westrheim, S. J., Snytko, V A. (1974). Length-weight relations of some Pacific ocean perch (Sebastes alutus) in the North Pacific Ocean. J. Fish. Res. Bd Can. 31: 363-366

White, M. L., Chittenden, M. E., Jr. (1977). Age determination, reproduction and population dynamics of the Atlantic croaker, Micropogonias undulatus. Fish. Bull. U.S. 75 : 109-123

Williams, G. C., Williams, D. C. (1973). Mortality rates of planktonic eggs of the cunner, Tautogolabrus adspersus (Walbaum), in Long Island Sound. In: Pacheco, A. L. (ed.) Proceedings of a workshop on egg, larval and juvenile stages of fish in Atlantic coast estuaries. U.S. National Marine Fisheries Sorricc, Middle Aubantic Fishenes Center Technical Publication No. 1, p. 181-189

Young, P. H. (1963). The kelp bass (Paralabrax clathrus) and its fishery, 1947-1958. Calif. Dept. Fish Game, Fish. Bull. No. 172

Zukowski, C. (1972). Growth and mortality of the Atlantic argentine, Argentina silus Ascanius, on the Nova Scotia Banks. ICNAF Res. Bull. 9: 109-115

Zweifel, J. R., Lasker, R. (1976). Prehatch and posthatch growth of fishes - a general model. Fish. Bull. U.S. 74: $609-621$

Zweifel, J. R., Smith, P. E. (1981). Estimates of abundance and mortality of larval anchovies (1951-75): application of a new method. Rapp. P.-v. Réun. Cons. int. Explor. Mer 178: $248-259$

This article was presented by Professor K. Banse; it was accepted for printing on September 25, 1986 